\title{
Somatostatin Interneurons of the Insula Mediate QR2-Dependent Novel Taste Memory Enhancement
}

\author{
Nathaniel L. Gould, ${ }^{1}$ @Sailendrakumar Kolatt Chandran, ${ }^{1}$ - $D$ Haneen Kayyal, ${ }^{1}$ Efrat Edry, ${ }^{1,2}$ and \\ (D)Kobi Rosenblum ${ }^{1,2}$
}

https://doi.org/10.1523/ENEURO.0152-21.2021

${ }^{1}$ Sagol Department of Neuroscience, University of Haifa, Haifa 3498838, Israel and ${ }^{2}$ Center for Gene Manipulation in the Brain, University of Haifa, Haifa 3498838 , Israel

\begin{abstract}
Forming long-term memories is crucial for adaptive behavior and survival in changing environments. The molecular consolidation processes which underlie the formation of these long-term memories are dependent on protein synthesis in excitatory and SST-expressing neurons. A centrally important, parallel process to this involves the removal of the memory constraint quinone reductase 2 (QR2), which has been recently shown to enhance memory consolidation for novel experiences in the cortex and hippocampus, via redox modulation. However, it is unknown within which cell type in the cortex removal of QR2 occurs, nor how this affects neuronal function. Here, we use novel taste learning in the mouse anterior insular cortex (alC) to show that similarly to mRNA translation, QR2 removal occurs in excitatory and SST-expressing neurons. Interestingly, both novel taste and QR2 inhibition reduce excitability specifically within SST, but not excitatory neurons. Furthermore, reducing QR2 expression in SST, but not in PV or excitatory neurons, is sufficient to enhance taste memory. Thus, QR2 mediated intrinsic property changes of SST interneurons in the alC is a central removable factor to allow novel taste memory formation. This previously unknown involvement of QR2 and SST interneurons in resetting alC activity hours following learning, describes a molecular mechanism to define cell circuits for novel information. Therefore, the QR2 pathway in SST interneurons provides a fresh new avenue by which to tackle age-related cognitive deficits, while shedding new light onto the functional machinations of long-term memory formation for novel information.
\end{abstract}

Key words: consolidation; insula; memory; novel; QR2; taste

\section{Significance Statement}

Quinone reductase 2 (QR2) removal from the cortex and hippocampus demarcates novelty, and facilitates memory formation for the associated events to a novel experience. The newly described QR2 pathway, and the circuit that is responsible for late consolidation of novel internal representations, are both currently being investigated and are not yet wholly understood. Presently, a hitherto unknown phenomenon of reduced SST activity in the hours following novel taste learning via QR2 removal is shown, providing a molecular mechanism to define a brain state enacted by distinct neuronal populations. This provides both new molecular and cellular information regarding an important time period in memory formation, and also describes the key cell types involved in the underlying circuit, which is as yet unexplored.

Received April 9, 2021; accepted June 17, 2021; First published September 13, 2021.

The authors declare no competing financial interests.
Author contributions: N.L.G., E.E., and K.R. designed research; N.L.G., S.K.C., H.K., and E.E. performed research; N.L.G., S.K.C., H.K., and K.R. analyzed data; N.L.G. and K.R. wrote the paper. 


\section{Introduction}

Learning new information about the environment is critical for behavioral adaptation and survival (Squire et al., 2015a; Eichenbaum, 2017). Novel taste learning, necessary to identify safe food, is predicated on the release of acetylcholine (ACh) in the anterior insular cortex (alC), the brain region which subserves taste learning and memory (Gutiérrez et al., 2003; Yiannakas and Rosenblum, 2017). For decades, researchers in the field of molecular mechanisms underlying memory consolidation and synaptic plasticity focused on protein synthesis regulation (Davis and Squire, 1984; Santini et al., 2014). Recently, we described a central pathway downstream of ACh in the alC that is necessary for novel taste memory formation, in which quinone reductase 2 (QR2) acts as a removable constraint, in parallel and possibly separately from proteostasis (Rappaport et al., 2015; Gould et al., 2020b). Although reduced QR2 expression may affect the cell in a number of ways (Olshina et al., 2020; Sonavane et al., 2020), we identified that by removing QR2, which continuously generates physiological levels of reactive oxygen species (ROS), the alC becomes less oxidized. Thus, levels of oxidized and deactivated voltage gated potassium channel Kv2.1 are reduced, hours following learning, presumably along with other redox sensitive cellular components. Ablation of this redox modulation pathway and novel taste memory formation, by scopolamine, is rescued by directly inhibiting the QR2 enzyme (Gould et al., 2020b). QR2 is therefore part of a necessary oxidative eustress mechanism that denotes a novel memory, distinguishing the internal representation formed for the experience compared with that of a familiar experience. However, the detailed cell type/s involved in this molecular process within the alC are unknown.

The alC is a complex cortical structure that associates external events with their visceral consequences and acts across several forms of learning and behavior (Gogolla, 2017). It is comprised of the granular alC ( $\mathrm{glC}$ ), disgranular alC (dglC), and agranular alC (aglC), in a dorsoventral arrangement, within which reside a wide variety of cell types. Part of the current effort in understanding memory formation lies in placing molecular classification to cell types within subregions that are themselves functionally classified (Sharma et al., 2020; Shrestha et al., 2020). One would assume that different neurons act in discrete, particular fashion, to accommodate cellular and molecular

This work was supported by the Israel Academy of Sciences and Humanities Grant 258/20 and the Deutsche Forschungsgemeinschaft Grant 3619/13 (to K. R.). N.G. is a recipient of the University of Haifa President Fellowship for Excellent PhD students. H.K. is a recipient of the Edmond de Rothschild's scholarship.

Acknowledgements: We thank all current members of the Rosenblum lab for their help and support, the veterinary team headed by Dr. Barak Carmi and Corina Dollingher, and the technical team headed by Yair Bellehsen.

Correspondence should be addressed to Kobi Rosenblum at kobir@ psy.haifa.ac.il.

https://doi.org/10.1523/ENEURO.0152-21.2021

Copyright @ 2021 Gould et al.

This is an open-access article distributed under the terms of the Creative Commons Attribution 4.0 International license, which permits unrestricted use, distribution and reproduction in any medium provided that the original work is properly attributed. processes that presumably underlie the formation, maintenance or retrieval of an internal representation (Kepecs and Fishell, 2014). The QR2 pathway has been shown to act $3 \mathrm{~h}$ following novel taste learning and, therefore, presents a target to define cells involved in the late phase of memory consolidation (Alberini and Kandel, 2014). Although the downstream molecular targets of QR2 are still poorly understood, we found that in the hippocampus, QR2 removal $3 \mathrm{~h}$ following novelty exerts an inhibitory effect within inhibitory neurons, by hyperpolarizing their resting membrane potential (RMP; Gould et al., 2020a). This is sufficient to induce a hippocampal "novelty state," allowing the enhanced memory encoding that is associated with contextual novelty. By locating QR2 removal in the alC, we may start to discover the effect of this newly described molecular pathway on the cell and circuit level which subserve novel taste memory formation, which currently represents a major open question. Here, we found that the QR2 pathway is primarily involved in alC inhibitory neurons, and in particular that it is activated within SST interneurons across all subregions of the alC. Additionally, we found that in correlation to QR2 pathway activation $3 \mathrm{~h}$ following novel taste consumption, SST interneurons show reduced intrinsic excitability and an increase in medium after-hyperpolarization (mAHP), an effect strongly replicated by QR2 inhibition specifically in these cells. Furthermore, reduced QR2 expression in SST interneurons alone is sufficient to enhance taste memory consolidation. This therefore connects the QR2 pathway to SST interneuron function, indicating the importance of both these molecular and cellular components within the emerging circuitry of normal novel taste memory formation.

\section{Materials and Methods}

\section{Subjects}

Male and female mice, 8-16 weeks old, weighing 20$30 \mathrm{~g}$ from the following strains were used: C57BL/6 (Envigo), Gad2-IRES-Cre, SST-IRES-Cre, B6 PV-Cre and VIP-IRES-Cre (The Jackson Laboratory stock \#010802, \#013044, \#008069, and \#010908, respectively). The mice were kept in a temperature-controlled facility $\left(22-24^{\circ} \mathrm{C}\right)$, on a 12/12 h light/dark cycle (light phase 7 A.M. to 7 P.M.) at the University of Haifa, with water and food provided ad libitum. Experimentation was approved by the University of Haifa Animal Care and Use Committee (license numbers: 437/16, 487/17, 488/17, and 631/19). Before experimentation, mice were allowed $7 \mathrm{~d}$ of acclimatization. Animals were handled in accordance with University of Haifa practices and standards, in compliance with the National Institutes of Health guidelines for the ethical treatment of animals.

\section{Animal behavior}

Mice were taught to drink water from pipettes (2 ml/pipette) once a day for $20 \mathrm{~min}$, over $3 \mathrm{~d}$. They were then given pipettes containing a novel taste (0.5\% saccharin). Following novel taste consumption, animals were killed 3 $\mathrm{h}$ later, at the time point when QR2 mRNA expression reduction is best measured (Rappaport et al., 2015). To 
assess long-term memory of incidental novel taste learning, as indicated by novel taste preference using a choice test, mice were given a pipette of water and a pipette of the novel taste $(2 \mathrm{ml}$ each), $48 \mathrm{~h}$ after the novel taste was first consumed. Memory of the novel taste was determined by calculating a preference index, by dividing the volume of novel taste by the total volume consumed, [novel taste/(novel taste + water)] $\times 100$ (Rosenblum et al., 1993).

\section{AAV plasmids and production of recombinant AAV vectors}

QR2 shRNA sequences (shNQO2 and scrambled control) were cloned into pAAV-Sico-Red plasmid, which was a gift from Eun Mi Hwang (Addgene plasmid \#84882; http://n2t.net/addgene:84882; RRID:Addgene_84882), using conventional cloning techniques. HEK293FT cells were seeded at 25-35\% confluence to produce AAV vectors, and were transfected $24 \mathrm{~h}$ later. The plasmids encoding AAV rep, cap of AAV1 and AAV2, and a vector plasmid for the rAAV cassette, expressing the relevant shRNA, were applied using the PEI method (Grimm et al., 2003; Edry et al., 2011). $72 \mathrm{~h}$ after transfection, the cells and medium were harvested, pelleted by centrifugation $(300 \times g)$, resuspended in lysis solution $(150 \mathrm{~mm} \mathrm{NaCl}$ and $50 \mathrm{~mm}$ Tris- $\mathrm{HCl}$; $\mathrm{pH} 8.5$ with $\mathrm{NaOH}$ ) and lysed via $\mathrm{X} 3$ freeze-thaw cycles. Treatment of the crude lysate with $250 \mathrm{U}$ benzonase (Sigma) per $1 \mathrm{ml}$ of lysate at $37^{\circ} \mathrm{C}$ for 1.5 $\mathrm{h}$ was then done, to degrade genomic and unpackaged AAV DNA, followed by centrifugation at $3000 \times g$ for $15 \mathrm{~min}$ to pellet cell debris. Heparin-agarose columns were used to purify the virus particles from the supernatant, which were then washed with PBS and concentrated with Amicon (Merck Millipore) columns. The resultant viral suspension was then aliquoted and stored at $-80^{\circ} \mathrm{C}$. Viral titer was determined by qPCR. AAV vectors used for injections had genomic titers ranging between $2 \times 10^{10}$ and $5 \times 10^{10}$ genome copies per milliliter (gc/ml). The AAV p315 (ssAAV-1/2mCaMKII $\alpha$-EGFP_2A_iCre-WPRE-SV40p(A), physical titer $4.6 \times 10^{12} \mathrm{vg} / \mathrm{ml}$ ) was purchased from the University of Zurich Viral Vector Facility (https://vvf.ethz.ch/), to express Cre under the CamKII promoter.

\section{Surgeries and viral vector injection}

Mice were anesthetized with ketamine and domitor $(0.5 \mathrm{mg} / \mathrm{kg}$ each), given an analgesic (norocarp, $0.5 \mathrm{mg} /$ $\mathrm{kg}$ ) and $40 \mathrm{~min}$ later were placed in a robot stereotaxic device (Neurostar). The scalp was opened, and bregma and $\lambda$ were marked as reference points for the drilling and injection site (coordinates for alC relative to bregma: AP $0.86 \mathrm{~mm}, \mathrm{ML} \pm 3.4 \mathrm{~mm}$, DV $4 \mathrm{~mm}$ ). Following syringe (Hamilton) insertion, 5 min were given before $0.2-$ to $0.8-\mu \mathrm{l}$ virus was injected, at $0.05 \mu \mathrm{l} / \mathrm{min}$ using StereoDrive and InjectoMate software (Neurostar). The syringe was then left in the injection site for a further 10 min to prevent capillary motion of the virus from the site. Upon completion, incisions were dressed with $5 \%$ synthomycine ointment (Rekah), sealed shut with Vetbond (3M), $0.5 \mathrm{mg} / \mathrm{kg}$ enrofloxacin (Baytril) was given and mice were administered
$0.25 \mathrm{mg} / \mathrm{kg}$ atipamezole hydrochloride (Antisedan) and placed in a heated recovery cage for 1-2 $\mathrm{h}$. A month-long period of mouse recovery and virus expression was then given, following which experimentation began.

\section{Brain dissection and tissue preparation}

Mice were swiftly killed by cervical dislocation, brains were removed and instantly flash frozen with liquid nitrogen and stored in $-80^{\circ} \mathrm{C}$. Brain sections and tissue punches were conducted in a Leica CM 1950 cryostat. Samples for qPCR were dissected from 1-mm-thick coronal slices (from bregma: AP $1.18 \mathrm{~mm}, \mathrm{ML} \pm 3 \mathrm{~mm}$, DV 3.6 $\mathrm{mm}$, to bregma: AP $0.14 \mathrm{~mm}, \mathrm{ML} \pm 3.6 \mathrm{~mm}$, DV $4.1 \mathrm{~mm}$, using Franklin and Paxinos, 2007) with a 1-mm diameter tissue punching device. Samples for RNAscope were sliced in 20- $\mu \mathrm{m}$ sections, from bregma AP 1.25-0.25 mm, mounted directly onto SuperFrost Ultra Plus Adhesion slides (Thermo Fisher Scientific) and kept in $-80^{\circ} \mathrm{C}$.

\section{RNA extraction and qPCR}

RNA extraction, cDNA generation and qPCR were conducted as previously described (Gould et al., 2020b). Briefly, RNA was extracted using Tri reagent. cDNA was then synthesized using the Applied Biosystems (Thermo Fisher Scientific) High Capacity cDNA Reverse Transcription (RT) kit, according to manufacturer's instructions. Taqman (Thermo Fisher Scientific) primers were then used to detect QR2 (Mm01332867_m1), GAPDH (Mm99999915_g1) and HPRT (Mm00446968_m1). A custom primer was made for the measurement of mCherry (forward primer, GGCGCCTACAACGT CAACAT; reverse primer, TCGGCGCGTTCGTACTGT; probe, ACAACGAGGACTACACCAT). Relative quantitation was done using the $2^{\Delta \Delta \mathrm{Ct}}$ method (Livak and Schmittgen, 2001).

\section{RNAscope and image processing}

Over two separate experiments, mice received either a familiar (water, or seventh exposure to saccharin) or a novel taste (first exposure to saccharin), were killed $3 \mathrm{~h}$ later and fresh frozen brains were sliced into $20-\mu \mathrm{m} \mathrm{sec-}$ tions in a Leica CM 1950 cryostat, and then mounted onto SuperFrost Ultra Plus Adhesion slides (Thermo Fisher Scientific). RNAscope (ACD) fluorescent in situ hybridization (FISH) was then conducted as previously described (Golden et al., 2019; Gould et al., 2020a) by an experimenter blind to the identity of the groups, according to the manufacturer's instructions, using probes for Gad1, Slc17a7 (vGlut), Sst, Pvalb (PV), and Vip to mark out cells and Nqo2 (QR2) to measure changes to QR2 within these cells. Upon completion, slices were mounted using ProLong Gold antifade (Thermo Fisher Scientific). Slides were then left overnight in the dark, at room temperature, and were moved to $4^{\circ} \mathrm{C}$ refrigeration for continued storage. Images of the fluorescently labeled cells and QR2 were acquired with an Olympus IX81 microscope and Cell Sense software. Images were taken such as to form a $\mathrm{z}$ stack of three layers, $1.5 \mu \mathrm{m}$ apart. The stacks were then used to deconvolute the images to remove background, nonspecific signal. The deconvoluted images were then 
exported as BigTIFF and further processing was conducted using FIJI (https://imagej.net/Fiji), where regions of interest (ROls) were manually drawn to denote alC subregions, using the Allen Mouse Brain Atlas (http://mouse. brain-map.org/) for reference (Dong, 2008). Standardized background noise reduction was then done using the BioVoxxel 'Convoluted Background Subtraction' FIJI plugin, with Gaussian filter selected and set at a radius of $100 \mu \mathrm{m}$, and images were then converted into binary masks (0-255). The FIJI binary process Erode was then used to remove remaining signal background noise, speckles and debris, until almost only whole bodied cells were left. The remaining cell bodies were then brought back to their original size using the Dilate FIJl binary function. When co probing for GAD and vGlut, GAD masks were subtracted from vGlut to prevent double counting. Masked, binary representations of the cells (GAD, vGlut, PV, SST, and VIP) were then selected, and ROls were generated for each cell mask, using the FIJI Analyze Particles function and providing a minimum size (100-200 $\mu \mathrm{m}^{2}$ ) to avoid counting any remaining debris or incomplete cell segments and other artifacts. The fluorescent QR2 signal was then measured within these cell-defined ROIs, using the FIJI Command Manager Measure function, and data were collated into relevant bins (e.g., alC subregion, layer). QR2 signal within these cells was then averaged for each animal, and each animals mean QR2 expression per brain area and cell type was then used. In order to minimize signal variation because of technical factors existing between experiments (e.g., probe shelf life, microscope light intensity), the average QR2 expression from every animal in each of the groups (i.e., novel, familiar) was divided by the control (familiar water) group mean QR2 signal, in each experiment separately. This normalized QR2 expression from each separate experiment was then combined, and a comparison was done between experimental groups (i.e., novel or familiar). When comparing relative contribution of QR2 signal from within excitatory or inhibitory cell types, cells were pooled from all animals in either familiar or novel taste groups and binned into either vGlut or GAD positive pools. The sum total QR2 signal from each of the pooled cell types was then divided by the total cell number within each experimental group (familiar or novel taste). Then, the reduction in QR2 signal was calculated by deducting the novel taste group QR2 signal, from each cell type, from that of the familiar taste group.

\section{Electrophysiology}

Tissue preparation

Mice were killed $3 \mathrm{~h}$ following water or saccharin consumption by decapitation, following anesthesia with isoflurane. Brain slices were cut at $300 \mu \mathrm{m}$ in coronal sections using a vibratome (Campden-1000) in ice chilled cutting solution (110 mm sucrose, $60 \mathrm{~mm} \mathrm{NaCl}, 3 \mathrm{~mm} \mathrm{KCl}$, $1.25 \mathrm{~mm} \mathrm{NaH}_{2} \mathrm{PO}_{4}, 28 \mathrm{~mm} \mathrm{NaHCO}_{3}, 0.5 \mathrm{~mm} \mathrm{CaCl}_{2}, 7 \mathrm{~mm}$ $\mathrm{MgCl}_{2}, 5 \mathrm{~mm} \mathrm{D}$-glucose, and $0.6 \mathrm{~mm}$ ascorbate, SigmaAldrich). The slices were placed in artificial CSF (ACSF; $125 \mathrm{~mm} \mathrm{NaCl}, 2.5 \mathrm{~mm} \mathrm{KCl}, 1.25 \mathrm{~mm} \mathrm{NaH}_{2} \mathrm{PO}_{4}, 25 \mathrm{~mm}$ $\mathrm{NaHCO}_{3}, 25 \mathrm{~mm}$ D-glucose, $2 \mathrm{~mm} \mathrm{CaCl}$, and $1 \mathrm{~mm}$
$\mathrm{MgCl}_{2}$, Sigma-Aldrich) for a $30 \mathrm{~min}$ recovery period at $37^{\circ} \mathrm{C}$ and then kept at room temperature for at least an additional $30 \mathrm{~min}$ before electrophysiological recording. Throughout, ACSF was continually gassed, using carbogen $\left(\mathrm{O}_{2} 95 \%, \mathrm{CO}_{2} 5 \%\right)$.

\section{Intracellular whole-cell recording}

Intrinsic properties were measured as previously reported (Chakraborty et al., 2017). Slices were placed in a recording chamber, following a 1-h recovery period in ACSF, and kept at $32-34^{\circ} \mathrm{C}$ while continuously being washed in carbogenated ACSF $(2 \mathrm{ml} / \mathrm{min})$. Pyramidal cells were identified using differential interference contrast microscopy (Olympus BX51WI), with $10 \times$ or $40 \times$ water immersion objectives. Images were acquired with a monitor using a charge-coupled device (CCD) camera (Dage MTI). In SST interneurons expressing Cre, a Cre-dependent mCherry reporter was used to positively identify the fluorescently labeled SST interneurons. A Multiclamp Axopatch 200B amplifier was used for recordings, which were digitized using a Digidata 1440 (Molecular Devices). Borosilicate glass pipettes (3-5 M) were used with a P-1000 electrode puller (Sutter Instruments) to make recording electrodes, which were then filled with $290 \mathrm{mOsm}, \mathrm{pH}$ 7.3, internal solution ( $130 \mathrm{~mm}$ K-gluconate, $5 \mathrm{~mm} \mathrm{KCl,} 10 \mathrm{~mm}$ HEPES, $2.5 \mathrm{~mm} \mathrm{MgCl}_{2}$, $0.6 \mathrm{~mm}$ EGTA, 4 mм Mg-ATP, $0.4 \mathrm{~mm}$ $\mathrm{Na}_{3} \mathrm{GTP}$, and $10 \mathrm{~mm}$ phosphocreatine, Sigma-Aldrich). Recordings were done from soma of pyramidal neurons and SST interneurons expressing mCherry, from the alC of C57BL/6 and SST Cre mice with $0.5 \mu \mathrm{m} \mathrm{S29434}$ (synthesized at the G-INCPM, Weizmann Institute) in $0.5 \% \mathrm{DMSO}$, or vehicle, in the patch pipette. No online correction was done for liquid junction potentials $(10 \mathrm{mV})$, and current clamp recordings were low-pass filtered at $10 \mathrm{kHz}$ and sampled at $50 \mathrm{kHz}$. Only cells with resistance smaller than $20 \mathrm{M} \Omega$ were included, once compensation for pipette capacitance and series resistance was done.

\section{Recording parameters}

RMP was measured $10 \mathrm{~s}$ following commencement of whole-cell recording, done by rupturing the membrane directly under the recording pipette $(<-50 \mathrm{mV})$. Injection of $500-\mathrm{ms}, 50-\mathrm{pA}$ current steps, from 50 to $400 \mathrm{pA}$, was used to measure neuron firing rate (while in current clamp, at the RMP of the cell). A hyperpolarizing current pulse $(-150 \mathrm{pA})$ elicited a voltage response which was used to calculate the input resistance (Rin). A sag ratio was calculated using $\left[\left(1-\Delta \mathrm{V}_{\mathrm{SS}} / \Delta \mathrm{V}_{\max }\right) \times 100 \%\right]$ of the voltage response to $-150 \mathrm{pA}$, as previously described (Song et al., 2015). Membrane time constant was determined by a single exponential fit to the first $100 \mathrm{~ms}$ of the raising phase of the neurons response to a 1-s, $-150-p A$ hyperpolarization step.

For $10 \mathrm{~ms}$, a series of brief, depolarizing currents were injected in 10-pA increments to measure single action potentials, following an initial assessment of the current required to elicit an action potential following $15 \mathrm{~ms}$ of current injection, using 50-pA steps. At $5 \mathrm{~ms}$, the first action potential was analyzed. A dV/dt curve was made for the action potential, using the $30-\mathrm{V} / \mathrm{s}$ point in the rising slope as threshold (Chakraborty et al., 2017). The duration of the action potential was measured at the half- 
A

B
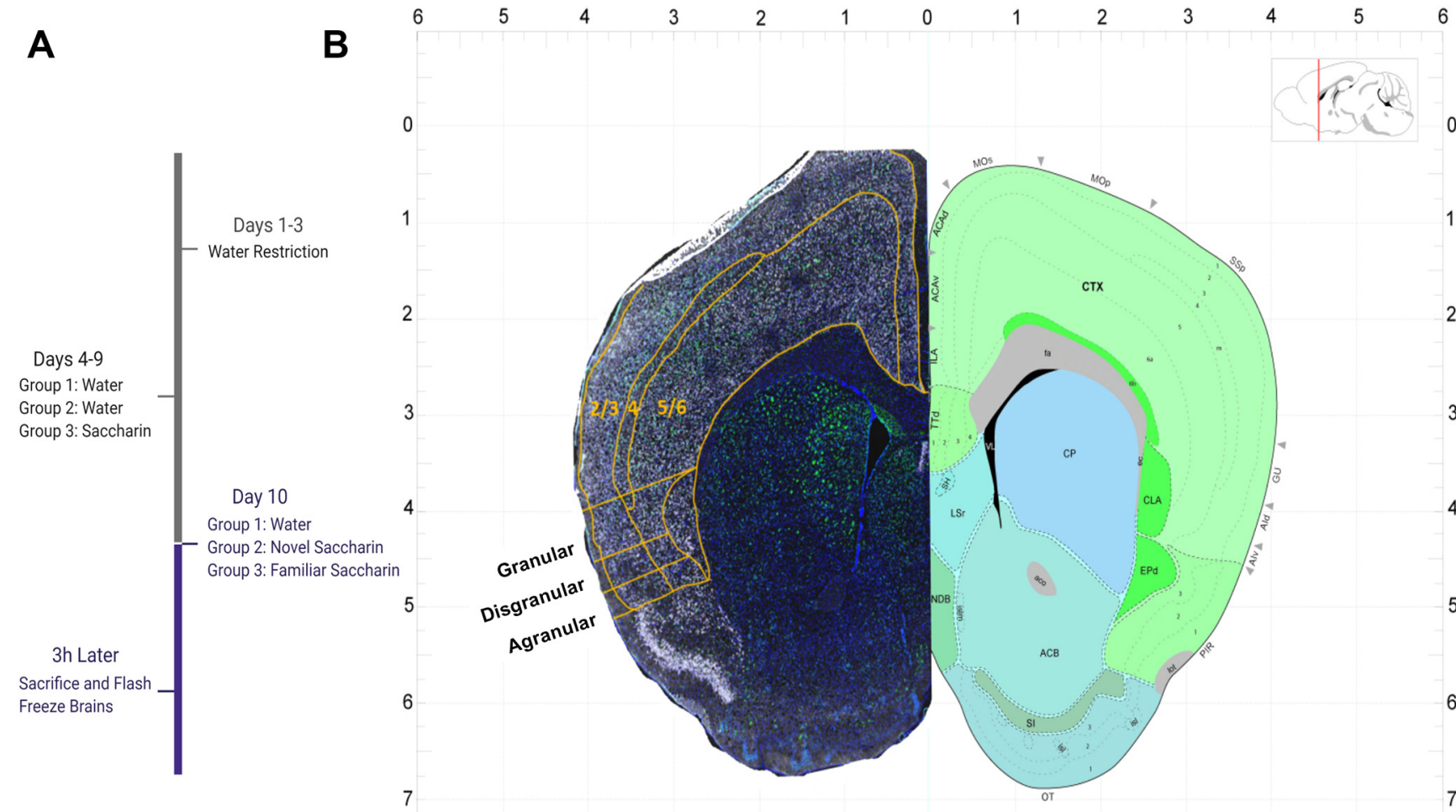

Coronal Level 42

Bregma $1.245 \mathrm{~mm}$

C
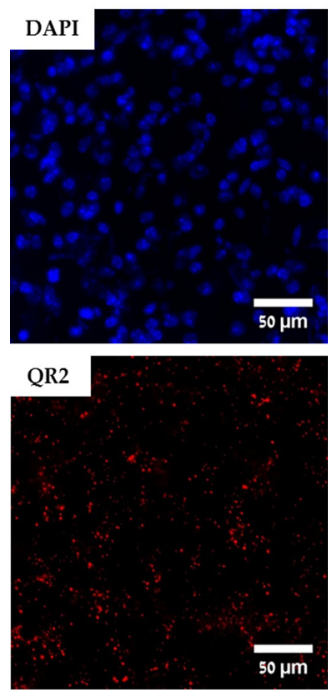

D

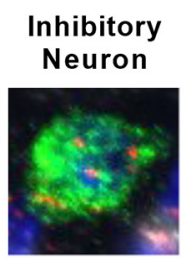

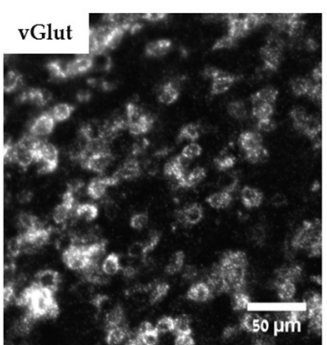

Composite
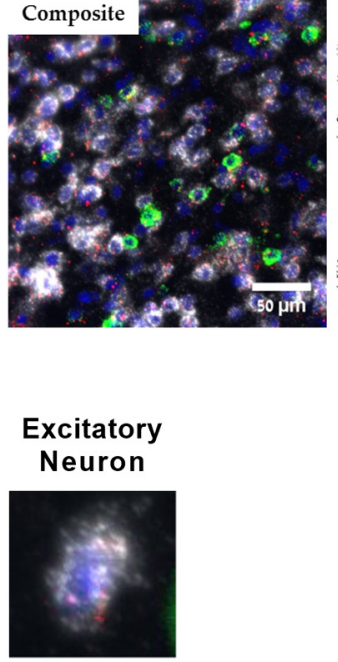

E Total Neurons IC

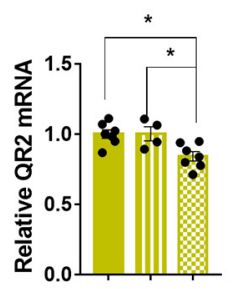

G Inhibitory Neurons IC

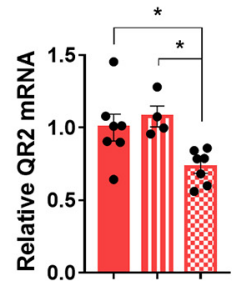

I Excitatory Neurons IC

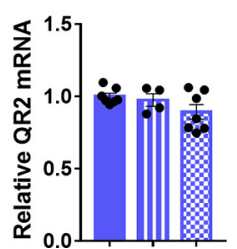

$\mathbf{F}$

Total Neurons of Control Cortex

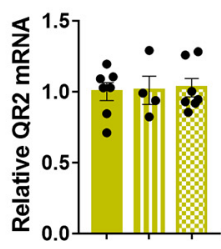

H

Inhibitory Neurons Control Cortex
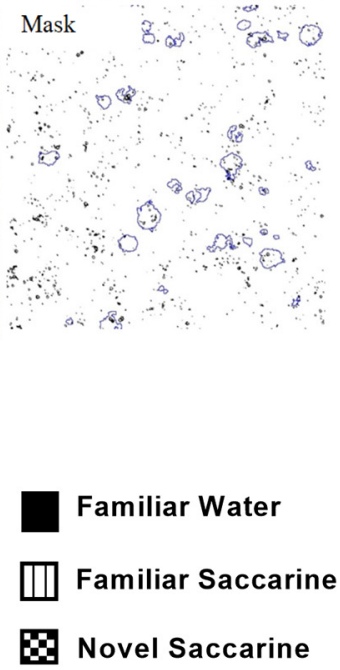

Figure 1. QR2 expression is reduced in inhibitory neurons of the alC $3 \mathrm{~h}$ following novel taste learning. $\boldsymbol{A}$, Mice were allocated randomly to three groups which consisted of water, familiarized saccharin and novel saccharin, and were killed $3 \mathrm{~h}$ following consumption. $\boldsymbol{B}$, Brains of mice killed $3 \mathrm{~h}$ following familiar or novel taste consumption were hybridized using RNAscope FISH probes. Relative QR2 mRNA expression in neurons was then measured and compared with familiar taste (water) controls. Brain atlas image 
continued

credit: Allen Institute. $\boldsymbol{C}$, Neurons were marked for vGlut (excitatory cells) or GAD (inhibitory cells) and QR2 mRNA was measured within cell outlines denoted by the cell markers. $\boldsymbol{D}$, Representative images of an inhibitory (green) and an excitatory (white) neuron, expressing QR2 (red). E, QR2 mRNA FISH-labeled expression levels are reduced in the alC following novel taste compared with either familiar tastes (familiar water $1 \pm 0.030 \mathrm{AU}, n=7$; familiar saccharin $1.001 \pm 0.050 \mathrm{AU}, n=4$; novel saccharin $0.841 \pm 0.032 \mathrm{AU}$, $n=7$; one-way ANOVA, $F_{(2,15)}=7.107, p=0.0067$; Tukey's multiple comparisons post hoc test, familiar water vs familiar saccharin, $p>0.9999$; familiar water vs novel saccharin, $p=0.0119$; familiar saccharin vs novel saccharin, $p=0.0310$ ). $\boldsymbol{F}$, No change to QR2 mRNA FISH-labeled expression levels were detected in the somatosensory cortex between the groups (familiar water $1.002 \pm 0.063 \mathrm{AU}, n=7$; familiar saccharin $1.011 \pm 0.099 \mathrm{AU}, n=4$; novel saccharin $1.028 \pm 0.064 \mathrm{AU}, n=7$; one-way ANOVA, $\left.F_{(2,15)}=0.04,115, p=0.9598\right)$. $G$, A reduction in QR2 mRNA FISH-labeled expression levels is seen in inhibitory neurons (familiar water $1 \pm 0.092 \mathrm{AU}, n=7$; familiar saccharin $1.077 \pm 0.071 \mathrm{AU}, n=4$; novel saccharin $0.730 \pm 0.044 \mathrm{AU}, n=7$; one-way ANOVA, $F_{(2,15)}=5.856, p=0.0132$; Tukey's multiple comparisons post hoc test, familiar water vs familiar saccharin, $p=0.7852$; familiar water vs novel saccharin, $p=0.0373$; familiar saccharin vs novel saccharin, $p=0.0224)$. $\boldsymbol{H}$, No change to QR2 mRNA FISH-labeled expression levels were detected in inhibitory neurons of the somatosensory cortex between the groups (familiar water $1 \pm 0.057 \mathrm{AU}, n=7$; familiar saccharin 1.011 $\pm 0.088 \mathrm{AU}, n=4$; novel saccharin 1.091 $\pm 0.128 \mathrm{AU}, n=7$; one-way ANOVA, $\left.F_{(2,15)}=0.2639, p=0.7716\right)$. $I$, QR2 mRNA FISH-labeled expression levels are not significantly reduced in excitatory neurons (familiar water $1 \pm 0.020 \mathrm{AU}, n=7$ mice; familiar saccharin $0.973 \pm 0.044 \mathrm{AU}, n=4$; novel saccharin $0.891 \pm 0.050 \mathrm{AU}, n=7$; one-way ANOVA, $F_{(2,15)}=2.187$, $p=0.1467)$. $\boldsymbol{J}$, No change to QR2 mRNA FISH-labeled expression levels were detected in excitatory neurons of the somatosensory cortex between the groups (familiar water $1 \pm 0.109 \mathrm{AU}, n=7$; familiar saccharin $1.008 \pm 0.108 \mathrm{AU}$, $n=4$; novel saccharin $0.866 \pm 0.103 \mathrm{AU}, n=7$; one-way ANOVA, $\left.F_{(2,15)}=0.5481, p=0.5892\right)$. Data are shown as mean $\pm \mathrm{SEM} ;{ }^{*} p<0.05$.

amplitude point of the spike. The equipotential point of the threshold and the spike peak were used to measure the spike amplitude. mAHP was measured with 3-nA high amplitude somatic current injections $3 \mathrm{~s}$ long, to initiate time locked action potential trains at $50 \mathrm{~Hz}(10-50 \mathrm{~Hz}, 1$ or $3 \mathrm{~s})$. A prolonged (20 s) AHP was caused by the action potential trains, the amplitudes and integrals of which increased in proportion to the number of spikes in the elicited train. AHP was then measured using the equipotential point of the threshold and the anti-peak of the same spike (Gulledge et al., 2013). During the duration of the experiment, series resistance, membrane capacitance and Rin were monitored, with exclusion of data showing $\geq 30 \%$ changes in these parameters.

\section{Statistical analysis}

Male and female subjects were randomly allocated to experimental groups. Group size range estimation was based on previously published results using similar methods, as well as an online power calculator (https://www. stat.ubc.ca/ rollin/stats/ssize/n2.html). Data obtained were tested for normality, using Shapiro-Wilk normality test. Normally distributed data were then analyzed by unpaired Student's $t$ test, one-way ANOVA or repeated measures two-way ANOVA, followed by Tukey's or Sidak's post hoc analysis. For non-parametric analysis, Mann-Whitney tests or Kruskal-Wallis followed by Dunn's multiple comparisons tests were conducted. All data are presented as means with SEM. All descriptive statistics, normality tests, parametric and non-parametric tests were conducted using GraphPad Prism 7 software.

\section{Results}

\section{QR2 expression is reduced in inhibitory neurons of the alC $3 \mathrm{~h}$ following novel taste learning}

In order to determine the cell type and location within the alC from which QR2 is removed following novel taste consumption, mice received either a familiarized taste (seventh exposure to $0.5 \%$ saccharin), water (highly familiar), or a novel taste (first exposure to $0.5 \%$ saccharin; Fig. $1 A$ ). The mice were then killed $3 \mathrm{~h}$ later, the time point at which QR2 removal is most notable when measuring mRNA using qPCR (Rappaport et al., 2015; Gould et al., 2020b), and RNAscope FISH was used on freshly frozen brain slices (Venniro et al., 2017). QR2 mRNA levels were probed by a second, blinded experimenter within excitatory (vGlut) and inhibitory (GAD1) neurons in the alC of all three groups of mice (Fig. 1B-D). Relative QR2 expression was derived by dividing the mean fluorescent signal of each mouse to that of the average QR2 signal measured in the control (familiar water) group. A significant reduction in QR2 mRNA expression was seen in the alC following novel taste only (Fig. 1E). In the control, somatosensory cortex, no change was detected (Fig. 1F). QR2 expression reduction in the alC was most distinctly detected in inhibitory neurons (Fig. $1 G)$, whereas excitatory neurons displayed only insignificantly reduced expression (Fig. 1/), while no significant changes were seen in either cell type in the control cortex (Fig. 1H,J). These results therefore point to inhibitory neurons as the main cell type in which QR2 expression reduction can be seen in the whole alC following novel taste.

\section{Reduced QR2 expression observed across the aIC is significant within inhibitory neurons in the granular subregion and in layers $2 / 3$ within both excitatory and inhibitory neurons following novel taste learning}

Overall, a relatively uniform reduction in QR2 expression was seen across the alC following novel taste consumption (Fig. 2F), in agreement with previously published qPCR results of whole alC homogenates (Rappaport et al., 2015; Gould et al., 2020b). Specifically, in excitatory neurons, an 8-18\% reduction in QR2 expression was seen across all the different subregions and layers of the alC (Fig. $2 A-E$, left panels). QR2 expression in excitatory neurons was most prominently and significantly reduced in layers $2 / 3$, while also trending most strongly in the dgIC. Inhibitory neurons similarly showed a uniform reduction in QR2 expression 
A

Excitatory Neurons Granular alC

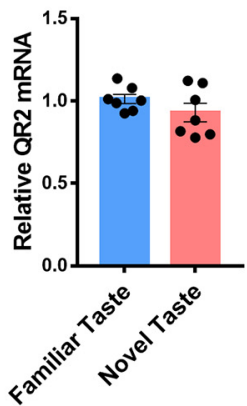

B

Excitatory Neurons Disgranular alC

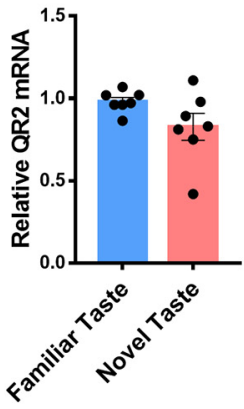

C

Excitatory Neurons Agranular alC

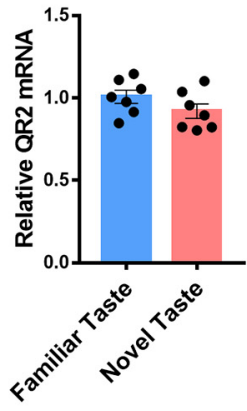

D

Excitatory Neurons Layers 2/3

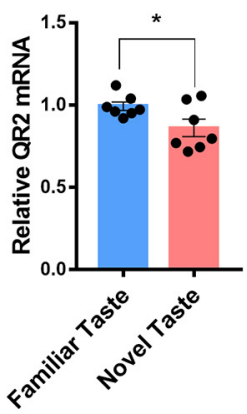

E

Inhibitory Neurons Granular alC

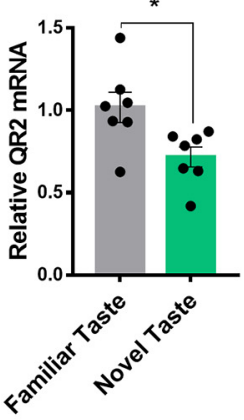

Inhibitory Neurons Disgranular alC

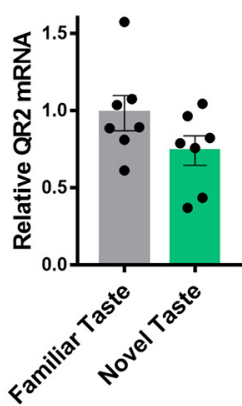

Inhibitory Neurons Agranular alC

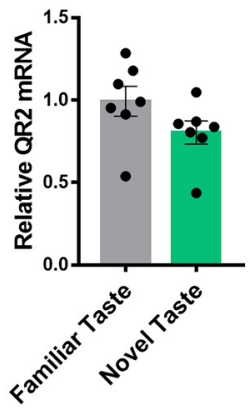

Inhibitory Neurons Layers $2 / 3$

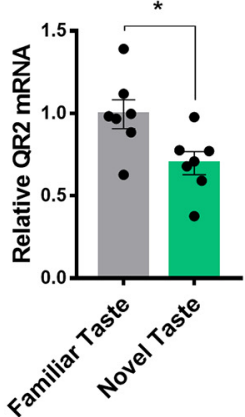

$\mathbf{F}$
Excitatory Neurons Layers 5/6
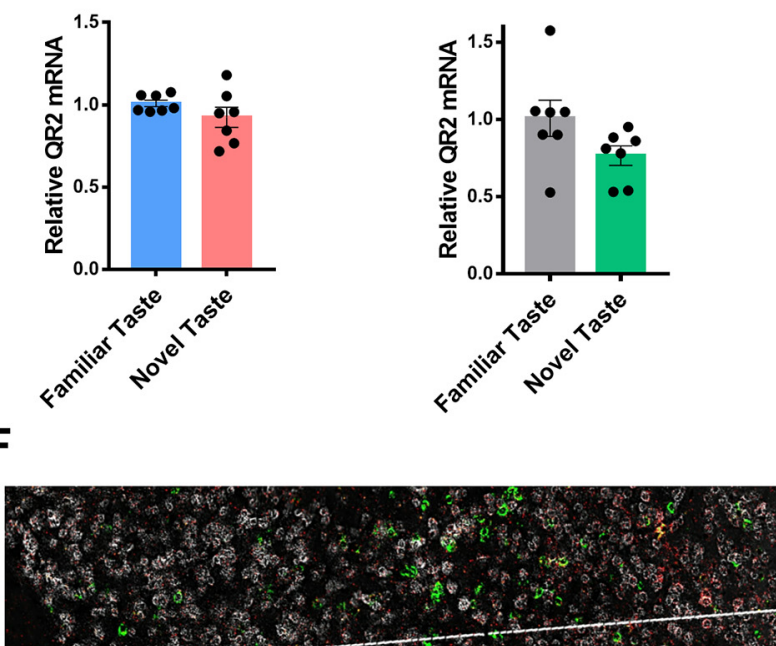

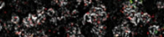
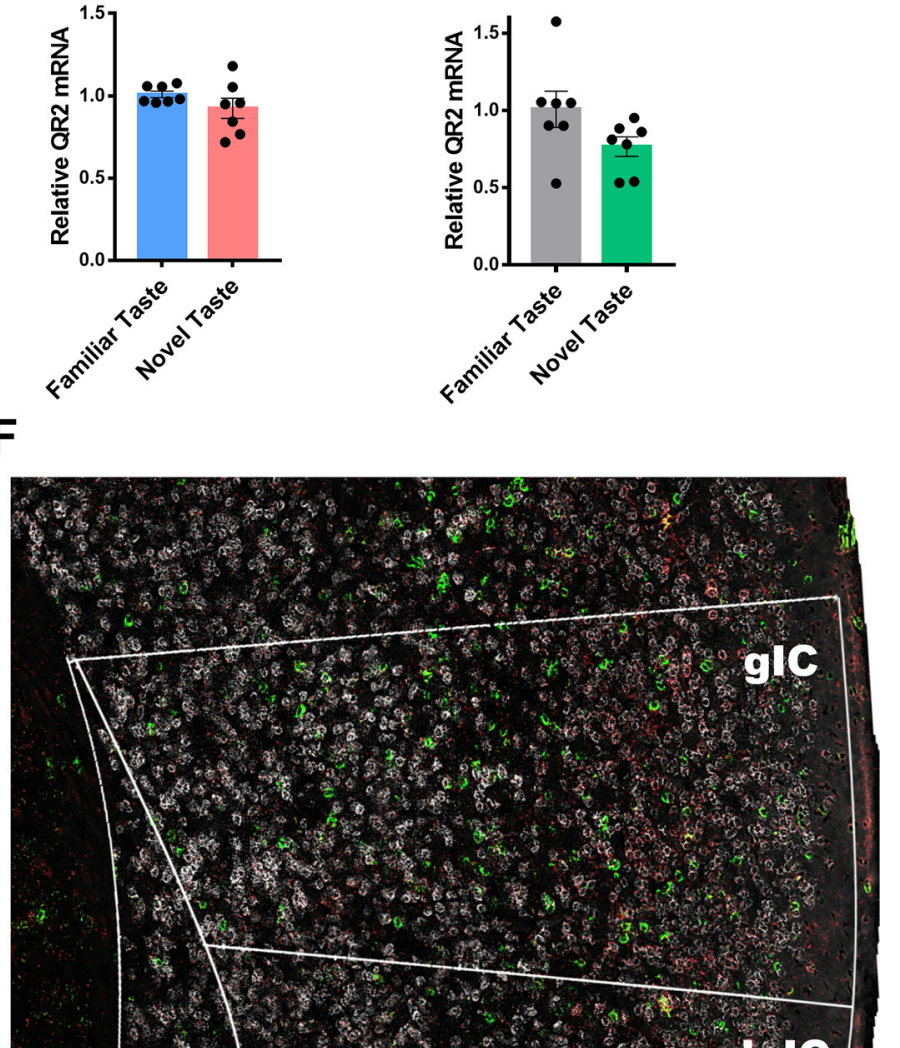
continued

Student's $t$ test, $t=1.304 \mathrm{df}=12, p=0.2167$ ) but show significant reduction in inhibitory neurons (familiar taste $1.018 \pm 0.092 \mathrm{AU}$, $n=7$; novel taste $0.716 \pm 0.061 \mathrm{AU}, n=7$; Student's $t$ test, $t=2.72 \mathrm{df}=12, p=0.0186)$. $\boldsymbol{B}, \mathrm{QR} 2 \mathrm{mRNA}$ FISH-labeled expression levels are not significantly reduced in the dgIC in both excitatory (familiar taste $0.980 \pm 0.024 \mathrm{AU}, n=7$; novel taste $0.827 \pm 0.081 \mathrm{AU}$, $n=7$; Student's $t$ test, $t=1.801 \mathrm{df}=12, p=0.0969$ ) and inhibitory neurons (familiar taste $0.984 \pm 0.114 \mathrm{AU}, n=7$; novel taste $0.741 \pm 0.095 \mathrm{AU}, n=7$; Student's $t$ test, $t=1.636 \mathrm{df}=12, p=0.1279)$. $\boldsymbol{C}$, QR2 mRNA FISH-labeled expression levels are not significantly reduced in the agIC in both excitatory (familiar taste 1.008 $\pm 0.039 \mathrm{AU}, n=7$; novel taste $0.920 \pm 0.043 \mathrm{AU}, n=7 ;$ Student's $t$ test, $t=1.478 \mathrm{df}=12, p=0.1652$ ) and inhibitory neurons (familiar taste $0.993 \pm 0.090 \mathrm{AU}, n=7$; novel taste $0.803 \pm 0.069 \mathrm{AU}, n=7$; Student's $t$ test, $t=1.658 \mathrm{df}=12, p=0.1233$ ). $\boldsymbol{D}$, QR2 mRNA FISH-labeled expression levels are reduced in layers $2 / 3$ in the alC in both excitatory (familiar taste $0.993 \pm 0.025 \mathrm{AU}, n=7$; novel taste $0.861 \pm 0.052 \mathrm{AU}, n=7$; Student's $t$ test, $t=2.247 \mathrm{df}=12$, $p=0.0443$ ) and inhibitory neurons (familiar taste $0.995 \pm 0.087 \mathrm{AU}, n=7$; novel taste $0.697 \pm 0.069 \mathrm{AU}, n=7$; Student's $t$ test, $t=2.665 \mathrm{df}=12, p=0.0206)$. $E, Q R 2 \mathrm{mRNA} F I S H$-labeled expression levels are not significantly reduced in layers $5 / 6$ in the alC in both excitatory (familiar taste $1.008 \pm 0.019 \mathrm{AU}, n=7$; novel taste $0.923 \pm 0.061 \mathrm{AU}, n=7$; Mann-Whitney test, $p=0.0973$ ) and inhibitory neurons (familiar taste $1.007 \pm 0.117 \mathrm{AU}, n=7$; novel taste $0.764 \pm 0.062 \mathrm{AU}, n=7$; Student's $t$ test, $t=1.816 \mathrm{df}=12$, $p=0.0944$ ). $\boldsymbol{F}$, Representative image of the mouse alC probed for vGlut (white), GAD (green), and QR2 (red). Outlines denote alC and subregions (gIC, granular IC; dgIC, disgranular IC; agIC, agranular IC). Data are shown as mean \pm SEM; ${ }^{*} p<0.05$.

across the alC following a novel taste, although to a greater extent, ranging between $20 \%$ and $30 \%$ less QR2 compared with following a familiar taste. Here, significant reduction in QR2 levels were measured in layers 2/3 once more, and also in the $\mathrm{glC}$, with otherwise most strongly trending QR2 expression reduction seen also in the dglC and layers 5/6 (Fig. 2A-E, right panels).

\section{SST interneurons are the primary locus of QR2 expression reduction in the alC following novel taste learning}

Next, we aimed to compare the relative QR2 levels found in excitatory and inhibitory neurons, and find the primary cell types within which QR2 expression and its suppression occur. However, distinction of single excitatory neurons is hampered in places where cell density is high and neurons overlap, thus creating difficulties for software to differentiate more than or equal to two neurons in those areas. This was not the case for the more sparsely populated, dispersed inhibitory neurons for which accurate cell count was not an issue. This resulted in a somewhat underestimated excitatory (and total) neuron cell count, and therefore a reduced ratio of excitatory-to-inhibitory neurons ( 3.6:1). However, despite this artificial reduction in total excitatory neuron number (Tremblay et al., 2016) by automated software analysis, on average inhibitory neurons were found to express roughly twice the amount of QR2 compared with excitatory neurons (Fig. 3A). It is therefore likely that because of the under estimation in excitatory neuron number, the ratio of excitatory to inhibitory neuronal QR2 expression in the alC is probably even lower. Furthermore, of the total 18\% reduction in QR2 expression measured $3 \mathrm{~h}$ following novel taste consumption within the two principal neuronal subtypes, $11 \%$ was measured in excitatory and $7 \%$ in inhibitory neurons (Fig. 3B). Therefore, although excitatory neurons actually outnumber inhibitory neurons by $\sim 7: 1$ in the cortex (Tremblay et al., 2016), there is a nearly $40 \%$ inhibitory to $60 \%$ excitatory neuron contribution to the overall QR2 expression reduction measured (Fig. 3C). This shows that QR2 is disproportionately expressed and modulated, subsequent to novel taste, within inhibitory interneurons in the alC.
Inhibitory interneurons are heterogeneous, with distinct genetic, morphologic, physiological and functional properties (Kepecs and Fishell, 2014). We therefore probed three of the major distinct interneuron subtypes present in the alC, namely PV, VIP, and SST (Rudy et al., 2011), which represent most $(\sim 85 \%)$ of the interneurons in the cortex and nearly all of those located in layers 2-6 (Kepecs and Fishell, 2014; Tremblay et al., 2016). Using RNAscope FISH, we found that, as described in the literature (Kim et al., 2017), the PV-to-SST ratio in the agranular regions is much lower than in granular cortical regions (Fig. 3D, left and right panels), making SST the predominant interneuron in the alC, while VIP interneurons are comparatively constrained to the superficial layers of the alC (Fig. 3D, middle panel). Within these three inhibitory neuron subtypes in the whole alC, a significant reduction in QR2 mRNA expression was seen only in SST interneurons, correlatively to novel taste consumption, while PV and VIP interneurons showed no significant changes (Fig. $3 E-G)$. When analyzing alC subregions, no changes were seen following novel taste consumption in PV or VIP interneurons in the gIC (PV, familiar $1 \pm 0.026 \mathrm{AU}, n=8$; $\mathrm{PV}$, novel $1.013 \pm 0.054 \mathrm{AU}, n=7$; Student's $t$ test, $t=0.2208$ $\mathrm{df}=13, p=0.8287$; VIP, familiar $1 \pm 0.062 \mathrm{AU}, n=8$; VIP, novel $1.081 \pm 0.175 \mathrm{AU}, n=7$; Student's $t$ test, $t=0.4621$ $\mathrm{df}=13, p=0.6517)$, the dgIC (PV, familiar $1 \pm 0.088 \mathrm{AU}$, $n=7$; PV, novel $0.994 \pm 0.135 \mathrm{AU}, n=7$; Student's $t$ test, $t=0.03,622 \mathrm{df}=12, p=0.9717$; VIP, familiar $1 \pm 0.087 \mathrm{AU}$, $n=8$; VIP, novel 1.255 $\pm 0.207 \mathrm{AU}, n=7$; Student's $t$ test, $t=1.185 \mathrm{df}=13, p=0.2571)$, the aglC (PV, familiar $1 \pm 0.140 \mathrm{AU}, n=7 ; \mathrm{PV}$, novel $0.942 \pm 0.047 \mathrm{AU}, n=7$; Student's $t$ test, $t=0.3876 \mathrm{df}=12, p=0.7051$; VIP, familiar $1 \pm 0.087 \mathrm{AU}, n=8 ; \mathrm{VIP}$, novel $1.255 \pm 0.207 \mathrm{AU}, n=7$; Student's $t$ test, $t=1.185 \mathrm{df}=13, p=0.2571$ ), layers $2 / 3$ (PV, familiar $1 \pm 0.044 \mathrm{AU}, n=8 ; \mathrm{PV}$, novel $1.037 \pm$ $0.069 \mathrm{AU}, n=7$; Student's $t$ test, $t=0.4553 \mathrm{df}=13$, $p=0.6564$; VIP, familiar $1 \pm 0.087 \mathrm{AU}, n=8$; VIP, novel $1.086 \pm 0.083 \mathrm{AU}, n=7$; Student's $t$ test, $t=0.7199$ $\mathrm{df}=13, p=0.4843$ ) or layers $5 / 6$ (PV, familiar $1 \pm 0.027$ $\mathrm{AU}, n=8$; PV, novel $1.035 \pm 0.057 \mathrm{AU}, n=7$; Student's $t$ test, $t=0.5666 \mathrm{df}=13, p=0.5807$; VIP, familiar $1 \pm 0.098 \mathrm{AU}$, $n=8$; VIP, novel $1.558 \pm 0.330 \mathrm{AU}, n=7$; Student's $t$ test, $t=1.713 \mathrm{df}=13, p=0.1104)$. In contrast, a significant reduction in QR2 was measured in SST neurons within the agIC, 
A

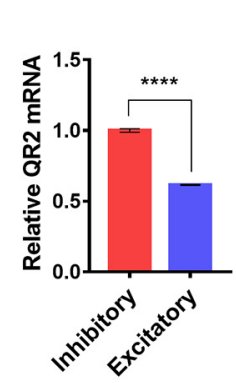

B

D

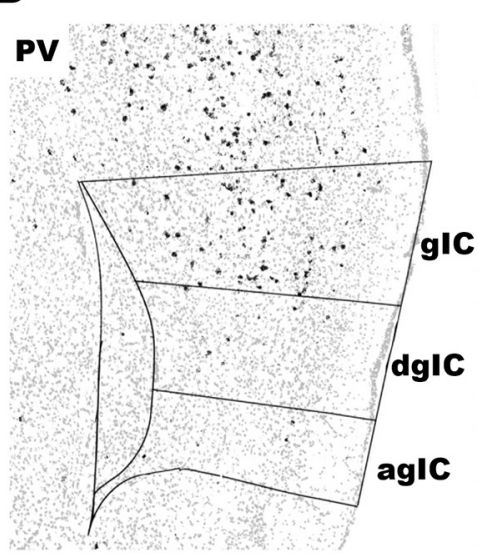

$\mathbf{F}$

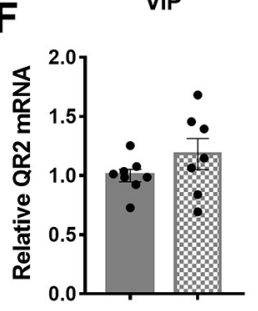

J

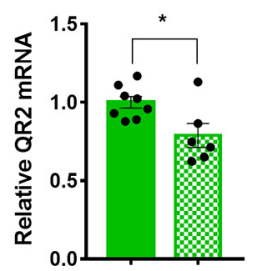

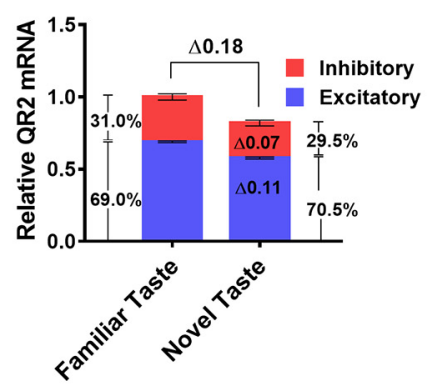

C

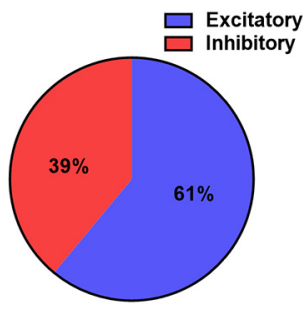

E

I

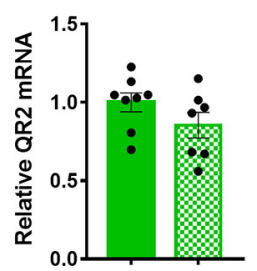

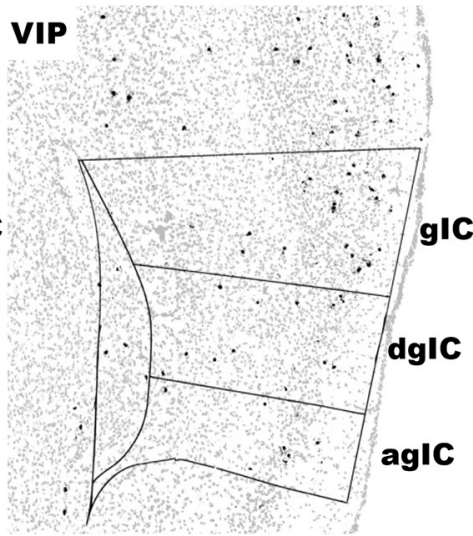

G

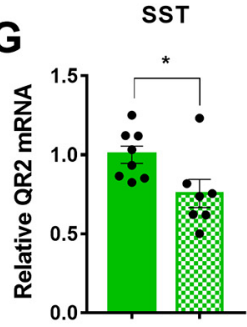

K

SST Layers 2/3

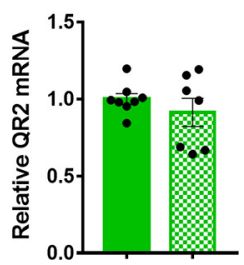

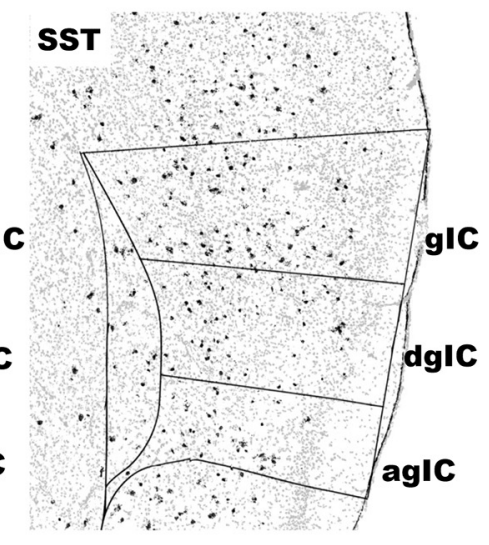

H

SST gIC

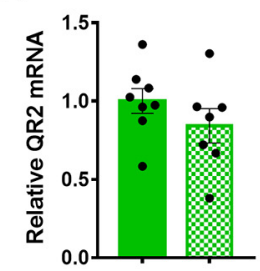

L SST Layers $5 / 6$

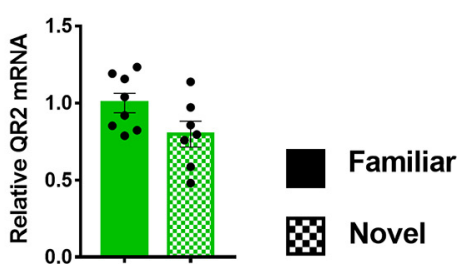

Figure 3. SST interneurons are the primary locus of QR2 expression reduction in the alC following novel taste learning. $\boldsymbol{A}$, Inhibitory neurons express roughly twice as much QR2 compared with excitatory neurons (inhibitory $1 \pm 0.012 \mathrm{AU}$, cells $n=12,592$ pooled from $n=14$ mice; excitatory $0.614 \pm 0.003$, cells $n=45,749$ pooled from $n=14$ mice; Mann-Whitney test, $p<0.0001$ ). B, Relative contribution of inhibitory and excitatory neurons to QR2 mRNA signal in both familiar and novel taste groups, as well as relative contribution to signal reduction following novel taste. C, Percentage of the total QR2 mRNA reduction measured in the alC, by cell type. $\boldsymbol{D}$, Representative distribution of PV, VIP, and SST interneurons in the alC of mice, using RNAscope FISH. Outlines denote alC and subregions (gIC, granular IC; dsIC, disgranular IC; agIC, agranular IC). E, QR2 mRNA FISH-labeled expression levels are not significantly altered in PV-expressing interneurons in the alC following novel taste consumption (PV, familiar $1 \pm 0.028 \mathrm{AU}, n=8$; PV, novel $0.980 \pm 0.043 \mathrm{AU}, n=7$; Student's $t$ test, $t=0.3954 \mathrm{df}=13, p=0.6989)$. $\boldsymbol{F}$, QR2 mRNA FISH-labeled expression levels are not significantly altered in VIP-expressing interneurons in the alC following novel taste consumption (VIP, familiar $1 \pm 0.052 \mathrm{AU}, n=8$; VIP, novel $1.182 \pm 0.132 \mathrm{AU}, n=7$ mice; Student's $t$ test, $t=1.342 \mathrm{df}=13, p=0.2025)$. G, QR2 mRNA FISH-labeled expression levels are reduced in SST-expressing interneurons in the alC following novel taste consumption (SST, familiar $1 \pm 0.054 \mathrm{AU}, n=8$; SST, novel $0.754 \pm 0.088 \mathrm{AU}, n=7$; Student's $t$ test, $t=2.413 \mathrm{df}=13, p=0.0313$ ). $\boldsymbol{H}$, QR2 mRNA FISH-labeled expression levels are not significantly reduced in SST-expressing interneurons in the gIC following novel taste consumption (SST, familiar $1 \pm 0.078 \mathrm{AU}, n=8$; SST, novel $0.841 \pm 0.109 \mathrm{AU}, n=7$; Student's $t$ test, $t=1.198 \mathrm{df}=13, p=0.2525)$. I, QR2 mRNA FISH-labeled expression levels are not significantly reduced in SST-expressing interneurons in the dgIC following novel taste consumption (SST, familiar $1 \pm 0.060 \mathrm{AU}$, $n=8$; SST, novel $0.854 \pm 0.082 \mathrm{AU}, n=7$; Student's $t$ test, $t=1.456 \mathrm{df}=13, p=0.1692$ ). J, QR2 mRNA FISH-labeled expression 
continued

levels are significantly reduced in SST-expressing interneurons in the agIC following novel taste consumption (SST, familiar $1 \pm 0.036 \mathrm{AU}, n=8$; SST, novel $0.788 \pm 0.076 \mathrm{AU}, n=6$; Student's $t$ test, $t=2.694 \mathrm{df}=12, p=0.0195)$. K, QR2 mRNA FISH-labeled expression levels are not significantly reduced in SST-expressing interneurons in layers 2/3 following novel taste consumption (SST, familiar $1 \pm 0.035 \mathrm{AU}, n=8$; SST, novel $0.912 \pm 0.090 \mathrm{AU}, n=7$; Student's $t$ test, $t=0.9477 \mathrm{df}=13, p=0.3606$ ). $L$, QR2 mRNA FISHlabeled expression levels are not significantly reduced in SST-expressing interneurons in layers $5 / 6$ following novel taste consumption (SST, familiar $1 \pm 0.062 \mathrm{AU}, n=8$; SST, novel $0.797 \pm 0.084 \mathrm{AU}, n=7$; Student's $t$ test, $t=1.956 \mathrm{df}=13, p=0.0722$ ). Data are shown as mean $\pm \mathrm{SEM} ;{ }^{*} p<0.05$.

with strong trends seen in other regions, most notably layers $5 / 6$ (Fig. $3 H-L$ ). This points to SST interneurons as the primary site of effect for the QR2 pathway, being the only major interneuron subtype assessed in the alC within which QR2 is naturally suppressed after novel taste experience.

\section{QR2 suppression reduces SST interneuron excitability and increases mAHP}

Following the cell type profile of QR2 suppression seen in the alC $3 \mathrm{~h}$ subsequent to novel taste consumption, we aimed to determine what effect reduced QR2 expression has on the cell types identified, namely SST interneurons and excitatory pyramidal neurons. To do so, SST-Cre mice (The Jackson Laboratory stock \#013044) injected with a Cre-dependent mCherry reporter, or wild-type (WT) mice, were given a familiar (water) or novel (saccharin $0.5 \%$ ) taste to drink. The mice were then killed 3 $\mathrm{h}$ later to perform whole-cell patch-clamp recordings of the intrinsic properties of SST or pyramidal neurons of the alC (Fig. 4A). Interestingly, $3 \mathrm{~h}$ following novel taste consumption, SST but not pyramidal neurons showed reduced firing frequency (Fig. 4B-E). Remarkably, by inhibiting QR2 in neurons of animals that drank a familiar taste (water), using $0.5 \mu \mathrm{m}$ S29434 (Ferry et al., 2010) within the recording pipette, the firing frequency of alC SST (Fig. 4H) but not pyramidal (Fig. 4/) neurons was reduced similarly, if more strongly, to that seen following novel taste (Fig. 4B-E). Additionally, the mAHP of SST but not pyramidal neurons was increased following novel taste consumption (Fig. 5/), and QR2 inhibition within SST neurons of animals that experienced a familiar taste mimicked the novel taste mediated effect (Fig. 4F,G). Other intrinsic properties measured were not significantly affected by novel taste consumption alone in either SST or excitatory neurons (Fig. 5A-H). However, QR2 inhibition in SST neurons of mice experiencing a familiar taste resulted in significantly more hyperpolarized RMP compared with SST neurons of mice experiencing a novel taste (Fig. 5A). Together, this provides both a cellular pattern and function for the QR2 pathway within the circuits of the alC in novel taste learning.

\section{Reduced QR2 expression in SST interneurons enhances novel taste memory formation}

To investigate whether the cellular pattern of reduced QR2 expression could also indicate QR2 mediated effect on memory and behavior, we used selective QR2 suppression in inhibitory or excitatory neurons of the alC. To do so, we generated an adeno associated viral vector containing the pSico-Red (Jung et al., 2016) construct to target QR2 mRNA for degradation on Cre recombinase activation (Fig. 6A). This was injected into the alC of GADCre transgenic mice (The Jackson Laboratory stock \#010802; Fig. 6B), or WT mice in tandem with another viral vector, expressing Cre under the CamKII promoter (see Materials and Methods). Mice were given a month to recover and then trained to drink from pipettes and consume a novel taste (saccharin), for which their memory was tested $48 \mathrm{~h}$ following learning, using a choice test (Fig. 6C). Mice expressing QR2 shRNA in inhibitory neurons (mCherry reporter expression in GAD CreScrambled $9.006 \pm 0.084 \Delta \mathrm{C}_{\mathrm{t}}$, GAD Cre-QR2 shRNA $\left.9.306 \pm 0.032 \Delta C_{t}\right)$ showed both significantly reduced QR2 expression (Fig. 6E) and improved memory compared with controls (Fig. 6D). In contrast, mice with QR2 shRNA targeted to excitatory neurons (mCherry reporter expression in CamKII Cre-Scrambled 8.345 $\pm 0.150 \Delta \mathrm{C}_{\mathrm{t}}$, CamKII Cre-QR2 shRNA 8.849 $\pm 0.089 \Delta \mathrm{C}_{\mathrm{t}}$ ) showed no improvement in novel taste memory (Fig. 6F), although a significant reduction in QR2 was measured (Fig. 6G). Following this result, we aimed to determine whether SST interneurons represent the major interneuron subtype contributing to the improvement in memory observed on selective QR2 degradation in inhibitory cells, in line with the intrinsic properties measured and in situ results obtained. Therefore, SST-Cre and PV-Cre animals (The Jackson Laboratory stock \#013044 and \#008069, respectively) were injected with Cre-dependent QR2 shRNA-expressing viral vectors. In PV Cre animals (mCherry reporter expression in PV Cre-Scrambled 11.798 \pm 0.711 $\Delta \mathrm{C}_{\mathrm{t}}$, PV Cre-QR2 shRNA $11.804 \pm 0.492 \Delta \mathrm{C}_{\mathrm{t}}$ ) a $\sim 6 \%$ (Fig. $6 /)$ and in SST Cre animals (mCherry reporter expression in SST Cre-Scrambled $10.939 \pm 0.326 \Delta \mathrm{C}_{\mathrm{t}}$, SST Cre-QR2 shRNA $11.346 \pm 0.783 \Delta \mathrm{C}_{\mathrm{t}}$ ) an $\sim 7 \%$ (Fig. $6 \mathrm{~K}$ ) non-significant reduction in total alC QR2 expression was measured by qPCR. These relatively small reductions to total alC QR2 expression are indicative of the relatively small number of cells SST and PV interneurons represent (between $2 \%$ and $6 \%$ ) from the total cell population measured in this way, within the vast majority of which (between 94\% and 98\%) QR2 was not targeted. In agreement with the in situ results (Fig. 3), QR2 shRNA expression in SST interneurons resulted in significantly better memory for the novel taste compared with controls (Fig. 6J), while no effect was seen in PV Cre animals (Fig. 6H). Combined, these results demonstrate that SST interneurons are the key locus of QR2 expression reduction involved in the consolidation of novel taste memory in the alC. 
A

$\underset{\text { Days } 1-3}{\text { Water Restriction }} \underset{3 h}{\text { Novel/Familiar Taste }} \rightarrow$ Sacrifice $\rightarrow$ Whole Cell Recording

B

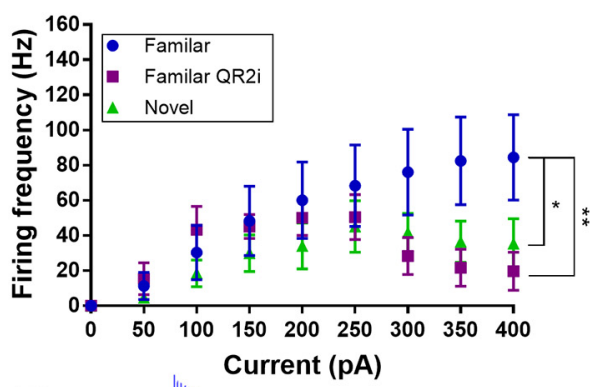

D

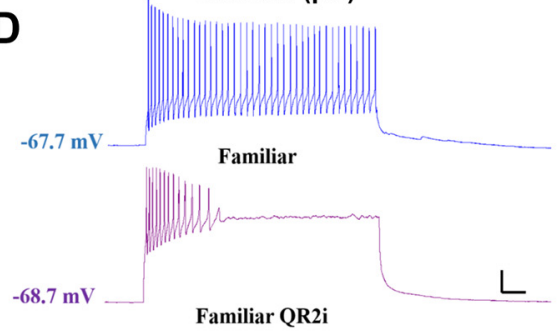

$-69.8 \mathrm{mV}$

$\mathbf{F}$

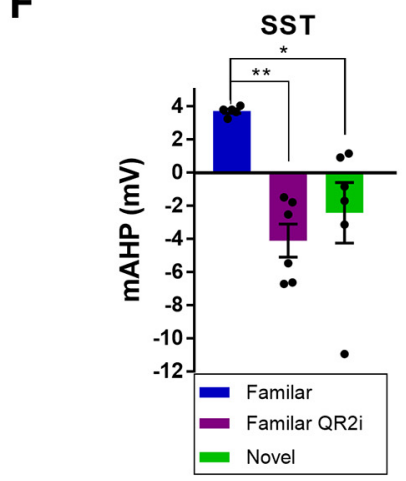

H

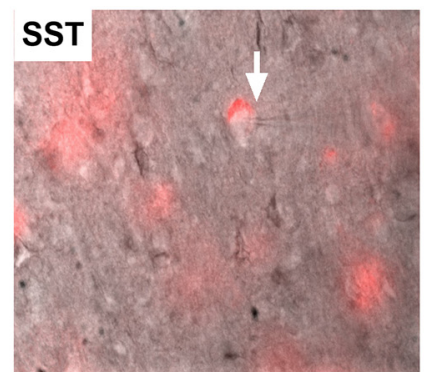

C

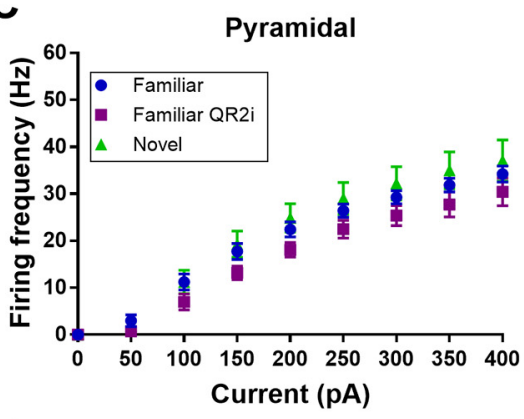

E
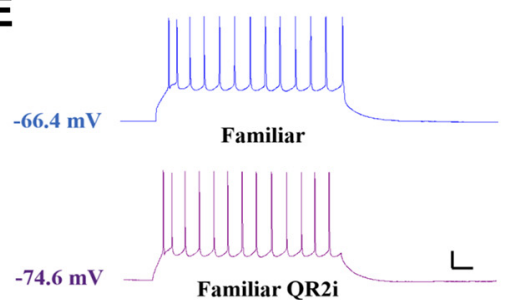

G

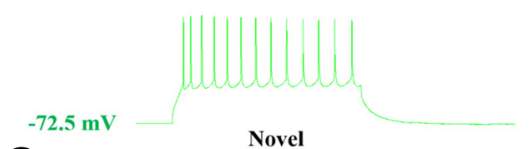

$$
\text { Pyramidal }
$$

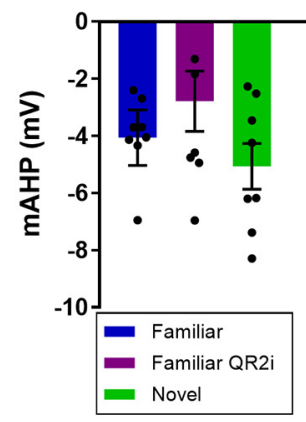

I

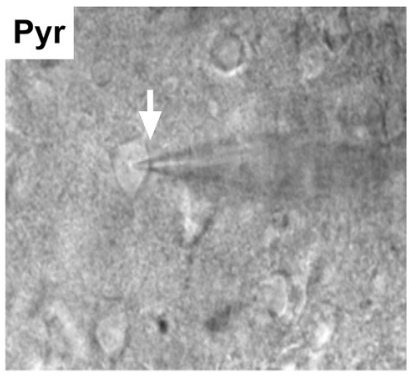

Figure 4. QR2 suppression reduces SST interneuron excitability and increases mAHP. $\boldsymbol{A}$, Mice were trained to drink from pipettes and were then given either a novel (saccharin) or familiar (water) taste. The mice were killed $3 \mathrm{~h}$ later, at a time QR2 is suppressed following novelty, and whole-cell patch recording was conducted in SST and pyramidal neurons. QR2 inhibitor (QR2i) was added into the recording pipette following familiar taste consumption, to compare with the novel taste group. $\boldsymbol{B}$, Experience of a novel taste reduces SST interneuron excitability in the alC $3 \mathrm{~h}$ following consumption and QR2 inhibition $3 \mathrm{~h}$ following a familiar taste mimics the reduced firing frequency following novelty [two-way repeated measures ANOVA, interaction $F_{(16,120)}=2.707, p<0.0011$; pulse $F_{(8,120)}=12.91, p<0.0001$; groups $F_{(2,15)}=1.526, p=0.2492$; subjects (matching) $F_{(15,120)}=10.88$, $p<0.0001$; Sidak's multiple comparisons test of familiar vs familiar QR2i at $300 \mathrm{pA}, p=0.0 .0365$; familiar vs familiar QR2i at $350 \mathrm{pA}, p=0$. 0.0047 , familiar vs 
continued

novel at 350, $p=0.0576$; familiar vs familiar QR2i at 400, $p=0.0023$, familiar vs novel at $400, p=0.0384$ ]. $\boldsymbol{C}$, Excitatory primary neurons of the alC show no change in firing frequency $3 \mathrm{~h}$ following novel taste consumption or inhibition of QR2 [two-way repeated measures ANOVA, Interaction $F_{(16,192)}=1.102$, $p<0.3555$; pulse $F_{(8,192)}=269.8, p<0.0001$; groups $F_{(2,24)}=1.873$, $p=0.1754$; subjects (matching) $\left.F_{(24,192)}=16.95, p<0.0001\right]$. $\boldsymbol{D}$, Representative traces from SST interneurons in the alC. Scale bar: $20 \mathrm{mV}$ (vertical), 50 ms (horizontal) from 350-pA current steps. $\boldsymbol{E}$, Representative traces from pyramidal neurons in the alC. Scale bar: $20 \mathrm{mV}$ (vertical), $50 \mathrm{~ms}$ (horizontal) from 250-pA current steps. $\boldsymbol{F}$, Experience of a novel taste increases SST interneuron $\mathrm{mAHP}$ in the alC $3 \mathrm{~h}$ following consumption and QR2 inhibition $3 \mathrm{~h}$ following a familiar taste mimics the increase in mAHP following novelty (familiar $3.714 \pm 0.131 \mathrm{mV}, n=5$ cells from $n=3$ mice; familiar QR2i $-4.103 \pm 0.995 \mathrm{mV}, n=6$ cells from $n=3$ mice; novel $-2.425 \pm 1.825 \mathrm{mV}, n=6$ cells from $n=4$ mice; one-way ANOVA, $F_{(2,14)}=9.71, p=0.0023$; Tukey's multiple comparisons post hoc test, familiar vs familiar QR2i, $p=0.0022$; familiar vs novel, $p=0.013 ;$ familiar QR2i vs novel, $p=0.6165)$. G, Experience of a novel taste does not affect pyramidal neuron mAHP in the alC $3 \mathrm{~h}$ following consumption and QR2 inhibition following a familiar taste has no effect on mAHP (familiar $-4.063 \pm 0.972 \mathrm{mV}, n=10 \mathrm{cells}$ from $n=3 \mathrm{mice}$; familiar QR2i $-2.788 \pm 1.053 \mathrm{mV}, n=8$ cells from $n=3$ mice; novel $-5.066 \pm 0.799 \mathrm{mV}, n=8$ cells from $n=3$ mice; one-way ANOVA, $\left.F_{(2,23)}=1.312, p=0.2887\right)$. $\boldsymbol{H}$, Representative image of mCherry-expressing SST interneuron in the alC. $\boldsymbol{I}$, Representative image of pyramidal neuron in the alC. Data are shown as mean $\pm \mathrm{SEM} ;{ }^{\star} p<0.05,{ }^{\star *} p<0.005$.

\section{Discussion}

Learning is a process defined by time, in which animals first acquire the information and later consolidate it molecularly (hours) and systemically (days to months; McGaugh, 2000; Squire et al., 2015b). Synaptic plasticity and molecular memory consolidation are defined by sensitivity to protein synthesis inhibitors and the involvement of specific mRNA translation factors such as elF2 $\alpha$ (Davis and Squire, 1984; Costa-Mattioli et al., 2007). Interestingly, we have recently shown that elF2 $\alpha$ mediated synaptic plasticity and memory consolidation in the hippocampus occurs in SST interneurons, as well as excitatory neurons (Sharma et al., 2020). In parallel, we described the QR2 pathway, which is a central molecular mediator of novel memory consolidation in the alC and hippocampus, in both taste and contextual modalities (Rappaport et al., 2015; Gould et al., 2020a,b). Activation of the pathway reduces QR2 expression, which alters the redox state of neurons, among other things, by reducing physiological ROS. In the hippocampus, we found this occurred mostly in interneurons, where initially high levels of QR2 are most notably reduced. In interneurons alone, inhibition of QR2 reduces excitability, pointing to QR2 mediated redox modulation of hippocampal interneuron intrinsic properties $3 \mathrm{~h}$ following learning (Gould et al., 2020a). Since QR2 thus potentially alters circuit states via interneuron activity to enhance the encoding of an internal representation for a novel event in the hippocampus, we aimed to identify how this pathway is activated in the alC, to help the relevant circuits for long-term novel memory formation there. The alC has laminated and stratified structures, within which reside diverse cell types (Gogolla, 2017; Kim et al., 2017). Here too, we showed that $3 \mathrm{~h}$ following a novel experience, QR2 is reduced from high baseline levels predominantly in interneurons, similarly to CA1, and that this occurs across this entire complex cortical structure, to varying degrees. Furthermore, of the three major interneuron subtypes assessed in the alC, QR2 expression is suppressed only within SST interneurons. Interestingly, however, the subregions within which QR2 expression reduction was seen in SST neurons does not entirely match that seen when taking the total inhibitory interneuron population. Namely, layers $2 / 3$, in which a significant reduction in QR2 was measured across all inhibitory neurons did not show similarly reduced levels in SST cells, pointing to perhaps another interneuron subtype which may play a role via the QR2 pathway. A possible candidate inhibitory cell subtype could be neuronderived neurotrophic factor (NDNF) interneurons, which have recently been described as a major subtype largely found in the superficial layers, and involved in brain state changes, as has been seen with QR2 elsewhere (Abs et al., 2018; Gould et al., 2020a; Cohen-Kashi Malina et al., 2021). Overall, a pattern of QR2 suppression in SST, and to a more modest extent excitatory neurons was found here. When comparing the effect on intrinsic properties that novel taste mediated QR2 suppression has on these two major cell types that contribute to the total observed reduction in QR2 expression, a stark difference emerges. At $3 \mathrm{~h}$ following novel taste, SST interneurons display attenuated intrinsic excitability, as well as an increase in mAHP, unlike excitatory neurons which remain unchanged compared with familiar taste at this time point. Inhibition of QR2 within SST interneurons, but not excitatory neurons of mice that drank a familiar taste alters these intrinsic properties similarly to novel taste, if to a far greater extent. This is likely indicative of the powerful pharmacological intervention (Ferry et al., 2010), and may also explain how QR2 inhibition using small molecules is able to improve normal, as well as impaired memory formation (Rappaport et al., 2015; Gould et al., $2020 b)$. There is also an interesting twist, since although the net effect on inhibitory neurons both in the hippocampus and alC following QR2 suppression is a reduction in firing rate, the way this occurs is different (Fig. 3; Gould et al., 2020b). A possible explanation is that these two brain regions have distinct interneuronal profiles (Pelkey et al., 2017), but also it may be because of the fact that in the hippocampus this was measured across all inhibitory neurons, whereas presently in the alC, it is measured specifically within SST interneurons. Excitatory neurons, on the other hand, show no such novelty or QR2 inhibition mediated effects at this time point, $3 \mathrm{~h}$ following the experience, which represents the optimal window in which to measure QR2 expression reduction. This may be because of the fact that SST interneurons express far higher levels of QR2 to begin with, 

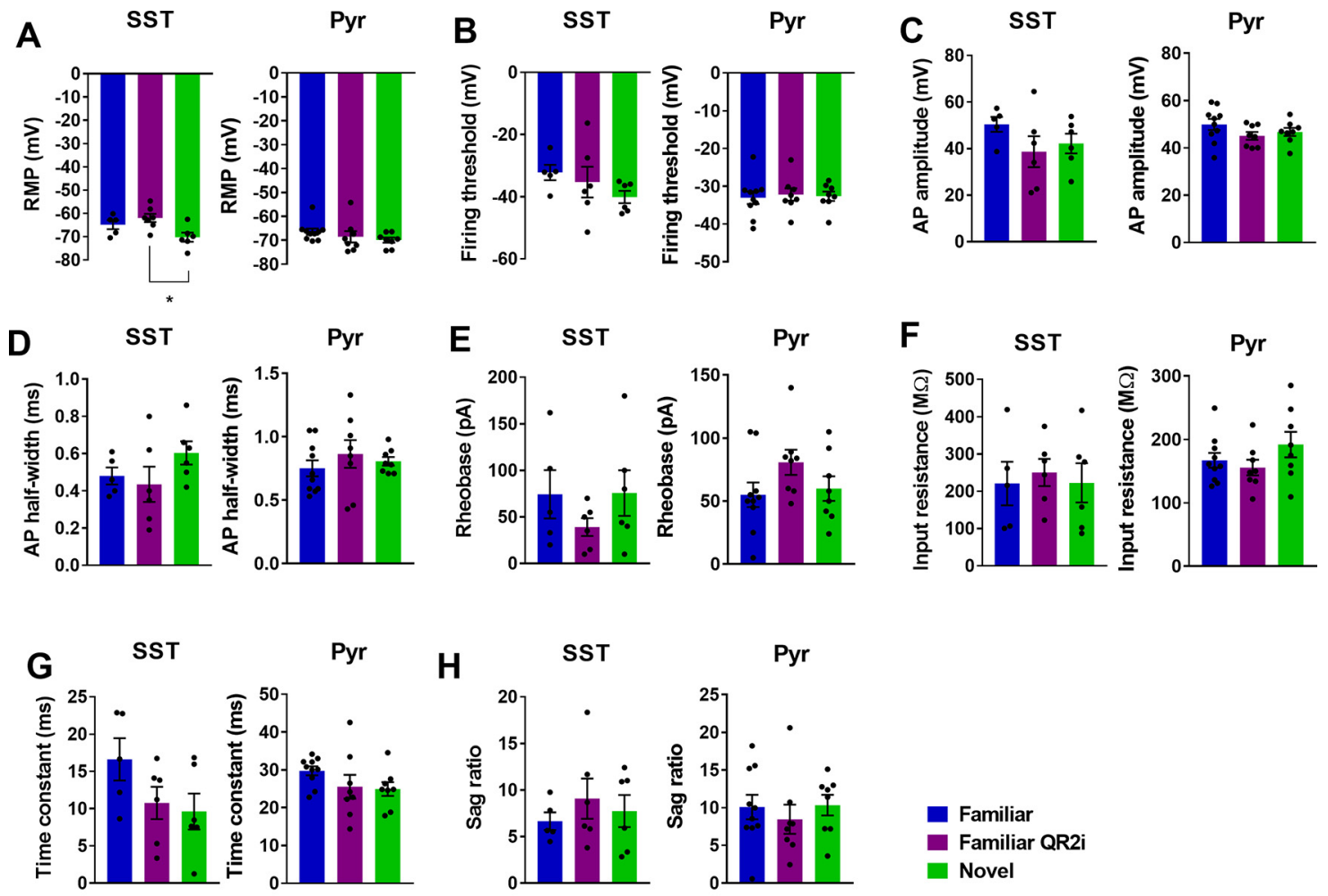

\section{I}
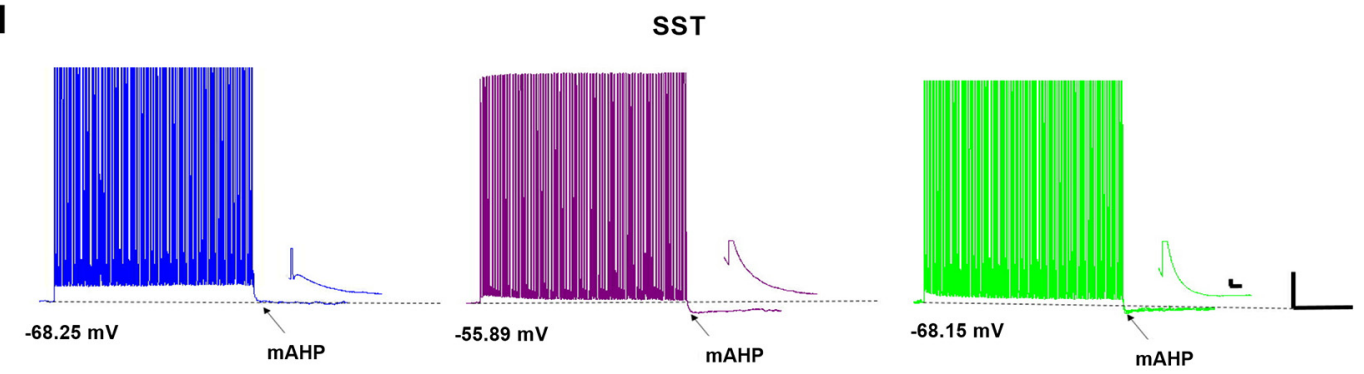

Pyr
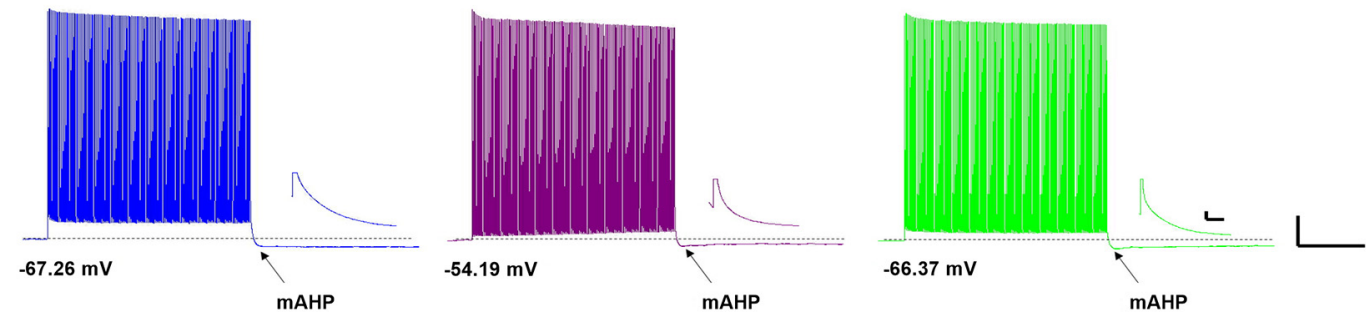

Figure 5. QR2 inhibition alters intrinsic properties of SST but not pyramidal neurons in the alC. $\boldsymbol{A}$, RMP of SST interneurons of the alC is hyperpolarized following novel taste experience compared with familiar taste with QR2 inhibition, but not when compared with familiar taste alone (familiar $-64.85 \pm 1.924 \mathrm{mV}, n=5$ cells from $n=3$ mice; familiar QR2i $-61.96 \pm 1.177 \mathrm{mV}, n=7 \mathrm{cells}$ from $n=3$ mice; novel $-70.21 \pm 1.948 \mathrm{mV}, n=6$ cells from $n=4$ mice; one-way ANOVA, $F_{(2,15)}=5.22, p=0.019$; Tukey's multiple comparisons post hoc test, familiar vs familiar QR2i, $p=0.5471$; familiar vs novel, $p=0.1687$; familiar QR2i vs novel, $p=0.0152$ ). RMP of pyramidal neurons of the alC remains unchanged $3 \mathrm{~h}$ following novel taste experience or QR2 inhibition (familiar $-66.39 \pm 1.271 \mathrm{mV}$, $n=10$ cells from $n=3$ mice; familiar QR2i $-68.54 \pm 2.336 \mathrm{mV}, n=8$ cells from $n=3$ mice; novel $-69.93 \pm 1.068 \mathrm{mV}, n=8 \mathrm{cells}$ from $n=3$ mice; Kruskal-Wallis test, $p=0.1301)$. $B$, Firing threshold of SST interneurons in the alC remains unchanged $3 \mathrm{~h}$ following novel taste experience or QR2 inhibition (familiar $-32.21 \pm 2.476 \mathrm{mV}, n=5$ cells from $n=3$ mice; familiar QR2i $-35.31 \pm 4.946 \mathrm{mV}$, $n=6$ cells from $n=3$ mice; novel $-40.13 \pm 1.965 \mathrm{mV}, n=6$ cells from $n=4$ mice; one-way ANOVA, $\left.F_{(2,14)}=1.274, p=0.3103\right)$. Firing threshold of pyramidal neurons in the alC remains unchanged $3 \mathrm{~h}$ following novel taste experience or QR2 inhibition (familiar $-33.05 \pm 1.647 \mathrm{mV}, \quad n=10$ cells from $n=3$ mice; familiar QR2i $-32.19 \pm 1.657 \mathrm{mV}, n=8$ cells from $n=3$ mice; novel $-32.64 \pm 1.218 \mathrm{mV}, n=8$ cells from $n=3$ mice; one-way ANOVA, $\left.F_{(2,23)}=0.07,867, p=0.9246\right)$. $C$, Action potential amplitude of SST interneurons in the alC remains unchanged $3 \mathrm{~h}$ following novel taste experience or QR2 inhibition (familiar $50.4 \pm 3.183 \mathrm{mV}, n=5$ 
continued

cells from $n=3$ mice; familiar QR2i $38.66 \pm 6.677 \mathrm{mV}, n=6$ cells from $n=3$ mice; novel $42.17 \pm 4.206 \mathrm{mV}, n=6 \mathrm{cells}$ from $n=4$ mice; one-way ANOVA, $\left.F_{(2,14)}=1.316, p=0.2993\right)$. Action potential amplitude of pyramidal neurons in the alC remains unchanged $3 \mathrm{~h}$ following novel taste experience or QR2 inhibition (familiar $49.91 \pm 2.328 \mathrm{mV}, n=10$ cells from $n=3$ mice; familiar QR2i $45.11 \pm 1.616 \mathrm{mV}, n=8$ cells from $n=3$ mice; novel $46.74 \pm 1.702 \mathrm{mV}, n=8$ cells from $n=3$ mice; one-way ANOVA, $F_{(2,23)}=1.562$, $p=0.2311)$. $\boldsymbol{D}$, Action potential half width of SST interneurons in the alC remains unchanged $3 \mathrm{~h}$ following novel taste experience or QR2 inhibition (familiar $0.48 \pm 0.045 \mathrm{~ms}, n=5$ cells from $n=3$ mice; familiar QR2i $0.435 \pm 0.094 \mathrm{~ms}, n=6$ cells from $n=3$ mice; novel $0.603 \pm 0.062 \mathrm{mV}, n=6$ cells from $n=4$ mice; one-way ANOVA, $\left.F_{(2,14)}=1.474, p=0.2624\right)$. Action potential half width of pyramidal neurons in the alC remains unchanged $3 \mathrm{~h}$ following novel taste experience or QR2 inhibition (familiar $0.751 \pm 0.063 \mathrm{~ms}, n=10 \mathrm{cells}$ from $n=3$ mice; familiar QR2i $0.863 \pm 0.109 \mathrm{~ms}, n=8$ cells from $n=3$ mice; novel $0.806 \pm 0.034 \mathrm{mV}, n=8$ cells from $n=3 \mathrm{mice}$; oneway ANOVA, $F_{(2,23)}=0.597, p=0.5588$ ). $E$, Rheobase of SST interneurons in the alC remains unchanged $3 \mathrm{~h}$ following novel taste experience or QR2 inhibition (familiar $74.4 \pm 25.97 \mathrm{pA}, n=5$ cells from $n=3$ mice; familiar QR2i $39.17 \pm 9.61 \mathrm{pA}, n=6$ cells from $n=3$ mice; novel $75.67 \pm 24.55 \mathrm{pA}, n=6$ cells from $n=4$ mice; one-way ANOVA, $\left.F_{(2,14)}=1.022, p=0.3851\right)$. Rheobase of pyramidal neurons in the alC remains unchanged $3 \mathrm{~h}$ following novel taste experience or QR2 inhibition (familiar $55.00 \pm 9.698 \mathrm{pA}, n=10$ cells from $n=3$ mice; familiar QR2i $80.75 \pm 10.03 \mathrm{pA}, n=8$ cells from $n=3$ mice; novel $59.88 \pm 9.781 \mathrm{pA}, n=8$ cells from $n=3 \mathrm{mice}$; oneway ANOVA, $\left.F_{(2,23)}=1.884, p=0.1747\right)$. $\boldsymbol{F}$, Input resistance of SST interneurons in the alC remains unchanged $3 \mathrm{~h}$ following novel taste experience or QR2 inhibition (familiar $220.8 \pm 58.51 \mathrm{M} \Omega, n=5$ cells from $n=3$ mice; familiar QR2i $250.3 \pm 36.47 \mathrm{M} \Omega, n=6$ cells from $n=3$ mice; novel $222.5 \pm 52.49 \mathrm{M} \Omega, n=6$ cells from $n=4$ mice; one-way ANOVA, $\left.F_{(2,14)}=0.1159, p=0.8914\right)$. Input resistance of pyramidal neurons in the alC remains unchanged $3 \mathrm{~h}$ following novel taste experience or QR2 inhibition (familiar $167.1 \pm 11.67$ $\mathrm{M} \Omega, n=10$ cells from $n=3$ mice; familiar QR2i $155.5 \pm 12.38 \mathrm{M} \Omega, n=8$ cells from $n=3$ mice; novel $191.9 \pm 20.18 \mathrm{M} \Omega, n=8$ cells from $n=3$ mice; one-way ANOVA, $\left.F_{(2,23)}=1.466, p=0.2517\right)$. $G$, Time constant of SST interneurons in the alC remains unchanged 3 $\mathrm{h}$ following novel taste experience or QR2 inhibition (familiar $16.63 \pm 2.828 \mathrm{~ms}, n=5$ cells from $n=3$ mice; familiar QR2i $10.76 \pm 2.169 \mathrm{~ms}, n=6$ cells from $n=3$ mice; novel $9.619 \pm 2.397 \mathrm{~ms}, n=6$ cells from $n=4$ mice; one-way ANOVA, $F_{(2,14)}=2.219$, $p=0.1455)$. Time constant of pyramidal neurons in the alC remains unchanged $3 \mathrm{~h}$ following novel taste experience or QR2 inhibition (familiar 29.73 $\pm 1.177 \mathrm{~ms}, n=10$ cells from $n=3$ mice; familiar QR2i $25.52 \pm 3.137 \mathrm{~ms}, n=8$ cells from $n=3$ mice; novel $24.93 \pm 1.837 \mathrm{~ms}, n=8$ cells from $n=3$ mice; one-way ANOVA, $\left.F_{(2,23)}=1.677, p=0.2090\right)$. $\boldsymbol{H}$, Sag ratio of SST interneurons in the alC remains unchanged $3 \mathrm{~h}$ following novel taste experience or QR2 inhibition (familiar $6.647 \pm 0.950, n=5$ cells from $n=3$ mice; familiar QR2i $9.08 \pm 2.158, n=6$ cells from $n=3$ mice; novel $7.742 \pm 1.724, n=6$ cells from $n=4$ mice; one-way ANOVA, $\left.F_{(2,14)}=0.4634, p=0.6384\right)$. Sag ratio of pyramidal neurons in the alC remains unchanged $3 \mathrm{~h}$ following novel taste experience or QR2 inhibition (familiar 10.09 $\pm 1.621, n=10$ cells from $n=3$ mice; familiar QR2i $8.454 \pm 1.934, n=8$ cells from $n=3$ mice; novel $10.33 \pm 1.376, n=8$ cells from $n=3$ mice; one-way ANOVA, $\left.F_{(2,23)}=0.3548, p=0.7051\right)$. $I$, Representative mAHP traces from SST and pyramidal neurons in the alC. Scale bars: $20 \mathrm{mV}$ and $1 \mathrm{~s}$ (large) and $5 \mathrm{mv}$ and $20 \mathrm{~ms}$ (small). Dashed line indicates baseline RMP. Data are shown as mean \pm SEM; ${ }^{*} p<0.05$.

so that the proportion of QR2 removed from within these cells is far greater than that in excitatory neurons. Another option is that the distinct membrane channel profile of SST interneurons is particularly sensitive to QR2 activity, and thus strongly affects SST intrinsic properties in a manner that is unique to these cells (Huntley et al., 2020). Indeed, establishing which ion channel/s are affected by QR2 and its inhibition remain an open question, and subject for further investigation.

An intriguing possibility lies in the concept of a second wave of proteostasis rearrangement, occurring $\geq 3 \mathrm{~h}$ following learning, proposed last century by Hansjurgen Matthies (Grecksch and Matthies, 1980; Frey et al., 1988), and later by others (Bekinschtein et al., 2007; MartínezMoreno, 2011). This second phase of molecular mechanisms underlying memory consolidation may result in different protein synthesis, depending on cell type, and may cause either QR2 activity or protein-protein interaction mediated shifts that are unique to SST interneurons. Indeed, this may equally be true for excitatory cells, where the slight decrease in QR2 observed may augment or affect longer term aspects of cell function, possibly via proteostasis (Olshina et al., 2020) for example, to stabilize the memory trace over longer time periods, differently from, but along with, SST interneurons. However, in terms of the measurable behavioral outcome of incidental taste learning, targeted removal of QR2 within inhibitory, but not excitatory neurons, enhances memory formation.
Moreover, it is within SST interneurons that genetic suppression of QR2 enables enhanced novel taste learning. This further corroborates and qualifies the cellular distinction found when assessing cellular expression and intrinsic property changes following QR2 pathway activation. In contrast, PV or VIP interneuron subtypes in the alC did not show changes in QR2 levels, and targeted QR2 suppression in PV interneurons did not affect taste memory. This may indicate that, in the present modality, novelty is represented as a cortical-state dictated by SST interneurons at the late stage of novel taste experience (UrbanCiecko and Barth, 2016; Fuchs et al., 2017; Cardin, 2019).

The QR2 pathway has an intercellular and intracellular affect. The former is by reducing the firing rate of interneurons, thus transiently altering E/I balance. The latter is redox modulation, which may have any number of molecular targets (Choi and Lipton, 2000; Reybier et al., 2011; Bogeski and Niemeyer, 2014; Gamper and Ooi, 2015; Lefaki et al., 2017; Lorenzen et al., 2017; Sies, 2017; Naseri Kouzehgarani et al., 2020). We have previously identified Kv2.1 as one such important target, which may explain the alterations in cell excitability we see presently (Cotella et al., 2012; Gould et al., 2020b). We expect other targets besides Kv2.1 to be identified in the future, and these may be cell type specific in their expression pattern, similarly to QR2 and elF2 $\alpha$. Certainly, how SST interneurons are affected by QR2 redox and via which channel or cellular component, or indeed whether QR2 pathway 
A

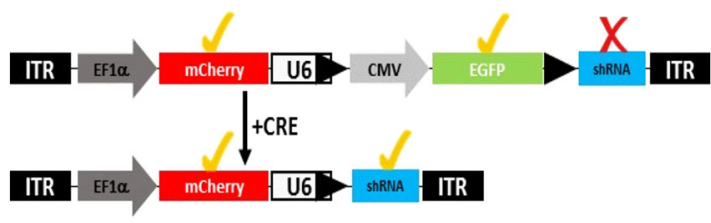

B

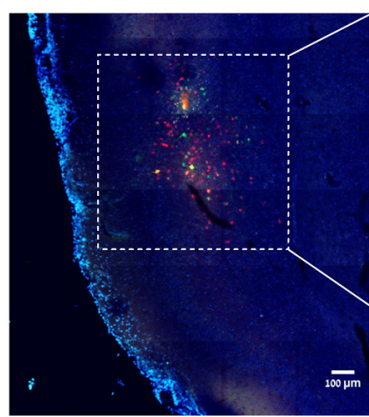

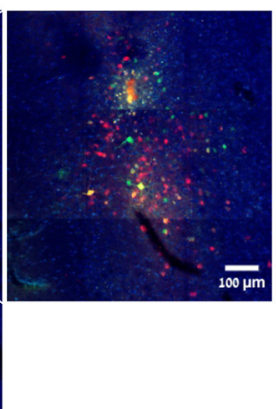

C

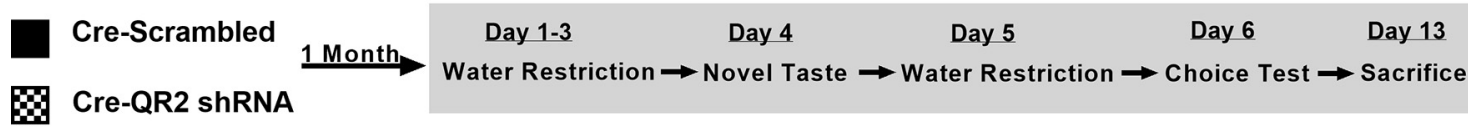

D

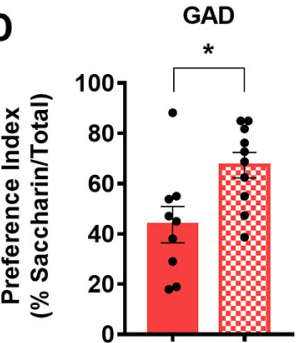

H

PV

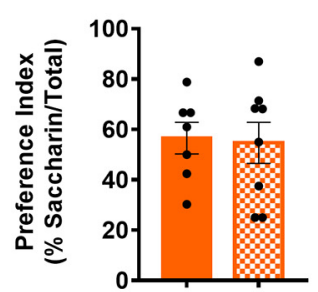

E

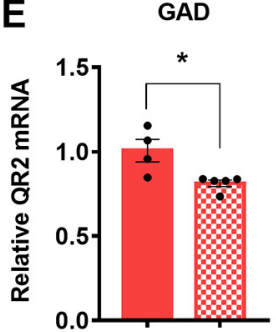

I

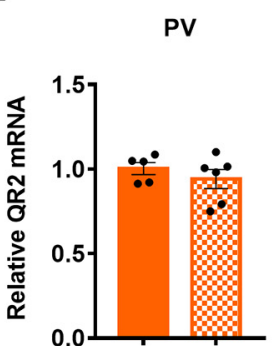

$\mathbf{F}$

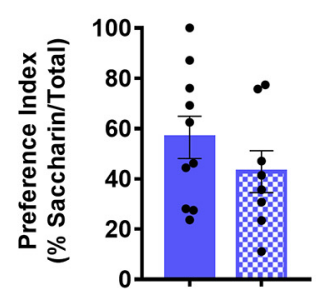

J

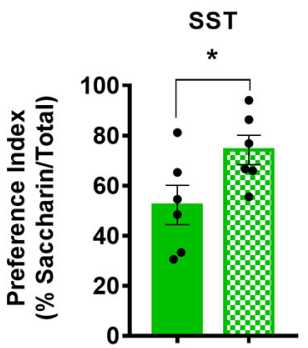

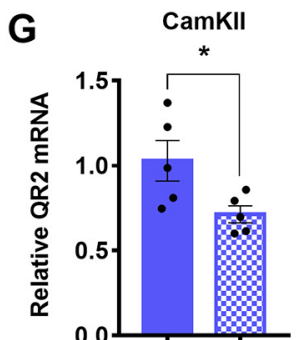

K

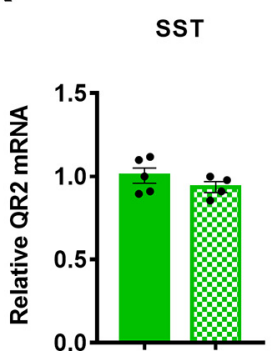

Figure 6. Reduced QR2 expression in SST interneurons enhances novel taste memory formation. $\boldsymbol{A}$, Schematic diagram of pAAV-SicoRed-QR2 shRNA vector before and after Cre-mediated recombination. $\boldsymbol{B}$, Representative image of Cre-dependent QR2 shRNA viral vector expression in GAD Cre mouse alC. $\boldsymbol{C}$, Mice were injected with the Cre-dependent QR2 shRNA or scrambled viral vector to the alC. A month later, they underwent novel taste learning, and $2 \mathrm{~d}$ after consuming the novel taste, they were given a choice test and a preference index was made. A week later, the mice were killed to assess infection efficacy, and the effect the expression of the virus had on local QR2 mRNA expression. $\boldsymbol{D}$, GAD Cre mice injected with Cre-dependent QR2 shRNA showed significantly improved novel taste memory compared with scrambled controls (GAD Cre-Scrambled 43.68 $\pm 7.218 \%, n=9$; GAD Cre-QR2 shRNA 67.31 $\pm 5.096 \%$; $n=10$; Student's $t$ test, $t=2.717 \mathrm{df}=17, p=0.0146)$. $E$, GAD Cre mice injected with Cre-dependent QR2 shRNA showed significantly reduced QR2 mRNA expression compared with scrambled controls (GAD Cre-Scrambled $1.007 \pm 0.0662^{-\Delta \Delta \mathrm{Ct}}, n=4$; GAD Cre-QR2 shRNA $0.813 \pm 0.0192^{-\Delta \Delta \mathrm{Ct}}, n=5$; Mann-Whitney test, $p=0.0159)$. $\boldsymbol{F}$, Mice co-expressing Cre under the CamKIl promoter and Cre-dependent QR2 shRNA in the alC show no significant change in novel taste memory compared with those injected with the scrambled Cre-dependent virus (CamKII CreScrambled 56.48 \pm 8.423\%, $n=10$; CamKII Cre-QR2 shRNA 42.84 $\pm 8.324 \%, n=8$; Student's $t$ test, $t=1.136 \mathrm{df}=16, p=0.2728$ ). G, A significant reduction in QR2 mRNA was measured in mice co-expressing Cre under CamKII promoter and Cre-dependent QR2 shRNA in the alC, compared with controls (CamKII Cre-Scrambled $1.027 \pm 0.1192^{-\Delta \Delta \mathrm{Ct}}, n=5$; CamKII Cre-QR2 shRNA $0.7122 \pm 0.0492^{-\Delta \Delta \mathrm{Ct}}, n=5$; Student's $t$ test, $t=2.435 \mathrm{df}=8, p=0.0409$ ). $\boldsymbol{H}$, PV Cre mice injected with Cre-dependent QR2 shRNA in the alC show no significant change in novel taste memory compared with those injected with the scrambled Cre-dependent virus (PV Cre-Scrambled $56.56 \pm 6.274 \%, n=7$; PV Cre-QR2 shRNA $54.67 \pm 8.180 \%, n=8$; Student's $t$ test, $t=0.1792 \mathrm{df}=13, p=0.8605)$. I, PV Cre mice injected with Cre-dependent QR2 shRNA showed insignificant QR2 mRNA expression reduction compared with scrambled controls (PV Cre-Scrambled $1.003 \pm 0.0352^{-\Delta \Delta C t}$, $n=5$; PV Cre-QR2 shRNA $0.940 \pm 0.0562^{-\Delta \Delta C t}, n=6$; Student's $t$ test, $\left.t=0.8789 \mathrm{df}=9, p=0.4023\right)$. J, SST Cre mice injected with Cre-dependent QR2 shRNA showed significantly improved novel taste memory compared with scrambled controls (SST Cre-Scrambled $52.26 \pm 7.868 \%, n=6$; SST Cre-QR2 shRNA 74.26 $\pm 5.843 \% ; n=6$; Student's $t$ test, $t=2.246 \mathrm{df}=10, p=0.0485$ ). $\boldsymbol{K}$, SST Cre mice injected with Cre-dependent QR2 shRNA showed insignificant QR2 mRNA expression reduction compared with scrambled controls (SST CreScrambled $1.004 \pm 0.0462^{-\Delta \Delta \mathrm{Ct}}, n=5$; SST Cre-QR2 shRNA $0.935 \pm 0.0322^{-\Delta \Delta \mathrm{Ct}}, n=4$; Student's $t$ test, $t=1.154 \mathrm{df}=7, p=0.2864$ ). Data are shown as mean $\pm \mathrm{SEM} ;{ }^{*} p<0.05$. 
activation causes other, non-redox mediated changes, are additional issues that require future efforts to decipher (Olshina et al., 2020; Sonavane et al., 2020; Hayat et al., 2021). Ultimately, how this altered SST interneuron activity subsequently affects the neuronal circuit/s involved in novel taste memory formation poses a substantial and important task for future research. To wit, the alC is not the only brain structure involved in novel taste learning, and future studies will have to integrate the local circuit within the alC, including the newly identified SST/QR2 component, as well as other saliency/novelty hubs such as the medial prefrontal cortex.

Here, as well as in recent findings, SST interneurons have emerged as an important focal point in which it is necessary to identify both molecular and circuit wide mechanisms underlying memory consolidation. The QR2 pathway is one such mechanism that must be further investigated in these cells, as it is the molecular determinant by which SST interneurons galvanize the distinct memory that is formed to differentiate novel from familiar.

\section{References}

Abs E, Poorthuis RB, Apelblat D, Muhammad K, Pardi MB, Enke L, Kushinsky D, Pu DL, Eizinger MF, Conzelmann KK, Spiegel I, Letzkus JJ (2018) Learning-related plasticity in dendrite-targeting layer 1 interneurons. Neuron 100:684-699.e6.

Alberini CM, Kandel ER (2014) The regulation of transcription in memory consolidation. Cold Spring Harb Perspect Biol 7: a021741.

Bekinschtein P, Cammarota M, Igaz LM, Bevilaqua LRM, Izquierdo I, Medina JH (2007) Persistence of long-term memory storage requires a late protein synthesis- and BDNF-dependent phase in the hippocampus. Neuron 53:261-277.

Bogeski I, Niemeyer BA (2014) Redox regulation of ion channels. Antioxid Redox Signal 21:859-862.

Cardin JA (2019) Functional flexibility in cortical circuits. Curr Opin Neurobiol 58:175-180.

Chakraborty D, Fedorova OV, Bagrov AY, Kaphzan H (2017) Selective ligands for $\mathrm{Na}+/ \mathrm{K}+$-ATPase $\alpha$ isoforms differentially and cooperatively regulate excitability of pyramidal neurons in distinct brain regions. Neuropharmacology 117:338-351.

Choi YB, Lipton SA (2000) Redox modulation of the NMDA receptor. Cell Mol Life Sci 57:1535-1541.

Cohen-Kashi Malina K, Tsivourakis E, Kushinsky D, Apelblat D, Shtiglitz S, Zohar E, Sokoletsky M, Tasaka G, Mizrahi A, Lampl I, Spiegel I (2021) NDNF interneurons in layer 1 gain-modulate whole cortical columns according to an animal's behavioral state. Neuron 109:2150-2164.e5.

Costa-Mattioli M, Gobert D, Stern E, Gamache K, Colina R, Cuello C, Sossin W, Kaufman R, Pelletier J, Rosenblum K, Krnjević K, Lacaille JC, Nader K, Sonenberg N (2007) elF2alpha phosphorylation bidirectionally regulates the switch from short- to long-term synaptic plasticity and memory. Cell 129:195-206.

Cotella D, Hernandez-Enriquez B, Wu X, Li R, Pan Z, Leveille J, Link CD, Oddo S, Sesti $F$ (2012) Toxic role of $K+$ channel oxidation in mammalian brain. J Neurosci 32:4133-4144.

Davis HP, Squire LR (1984) Protein synthesis and memory: a review. Psychol Bull 96:518-559.

Dong HW (2008) The Allen reference atlas: a digital color brain atlas of the C57BI/6J male mouse. Hoboken: Wiley Inc.

Edry E, Lamprecht R, Wagner S, Rosenblum K, Kittler J (2011) Virally mediated gene manipulation in the adult CNS. Front Mol Neurosci 4:57.

Eichenbaum H (2017) Memory: organization and Control. Annu Rev Psychol 68:19-45.
Ferry G, Hecht S, Berger S, Moulharat N, Coge F, Guillaumet G, Leclerc V, Yous S, Delagrange P, Boutin JA (2010) Old and new inhibitors of quinone reductase 2. Chem Biol Interact 186:103-109.

Franklin KBJ, Paxinos G (2007) The mouse brain in stereotaxic coordinates, Ed 3. New York: Academic Press/Elsevier.

Frey U, Krug M, Reymann KG, Matthies H (1988) Anisomycin, an inhibitor of protein synthesis, blocks late phases of LTP phenomena in the hippocampal CA1 region in vitro. Brain Res 452:57-65.

Fuchs T, Jefferson SJ, Hooper A, Yee PH, Maguire J, Luscher B (2017) Disinhibition of somatostatin-positive GABAergic interneurons results in an anxiolytic and antidepressant-like brain state. Mol Psychiatry 22:920-930.

Gamper N, Ooi L (2015) Redox and nitric oxide-mediated regulation of sensory neuron ion channel function. Antioxid Redox Signal 22:486-504.

Gogolla N (2017) The insular cortex. Curr Biol 27:R580-R586.

Golden SA, Jin M, Heins C, Venniro M, Michaelides M, Shaham Y (2019) Behavioral/cognitive nucleus accumbens Drd1-expressing neurons control aggression self-administration and aggression seeking in mice. J Neurosci 39:2483-2496.

Gould NL, Sharma V, Hleihil M, Kolatt Chandran S, David O, Edry E, Rosenblum K (2020a) Dopamine-dependent QR2 pathway activation in CA1 interneurons enhances novel memory formation. J Neurosci 40:8698-8714.

Gould NL, Elkobi A, Edry E, Daume J, Rosenblum K (2020b) Muscarinic-dependent miR-182 and QR2 expression regulation in the anterior insula enables novel taste learning. eNeuro 7: ENEURO.0067-20.2020.

Grecksch G, Matthies H (1980) Two sensitive periods for the amnesic effect of anisomycin. Pharmacol Biochem Behav 12:663-665.

Grimm D, Kay MA, Kleinschmidt JA (2003) Helper virus-free, optically controllable, and two-plasmid-based production of adeno-associated virus vectors of serotypes 1 to 6 . Mol Ther 7:839-850.

Gulledge AT, Dasari S, Onoue K, Stephens EK, Hasse JM, Avesar D (2013) A sodium-pump-mediated afterhyperpolarization in pyramidal neurons. J Neurosci 33:13025-13041.

Gutiérrez R, Téllez LA, Bermúdez-Rattoni F (2003) Blockade of cortical muscarinic but not NMDA receptors prevents a novel taste from becoming familiar. Eur J Neurosci 17:1556-1562.

Hayat F, Sonavane M, Makarov MV, Trammell SAJ, McPherson P, Gassman NR, Migaud ME (2021) The biochemical pathways of nicotinamide-derived pyridones. Int J Mol Sci 22:1-27.

Huntley MA, Srinivasan K, Friedman BA, Wang TM, Yee AX, Wang Y, Kaminker JS, Sheng M, Hansen DV, Hanson JE (2020) Genomewide analysis of differential gene expression and splicing in excitatory neurons and interneuron subtypes. J Neurosci 40:958-973.

Jung JY, Lee SE, Hwang EM, Lee CJ (2016) Neuronal expression and cell-type-specific gene-silencing of Best1 in thalamic reticular nucleus neurons using pSico-red system. Exp Neurobiol 25:120129.

Kepecs A, Fishell G (2014) Interneuron cell types are fit to function. Nature 505:318-326.

Kim Y, Yang GR, Pradhan K, Venkataraju KU, Bota M, García del Molino LC, Fitzgerald G, Ram K, He M, Levine JM, Mitra P, Huang ZJ, Wang XJ, Osten P (2017) Brain-wide maps reveal stereotyped cell-type-based cortical architecture and subcortical sexual dimorphism. Cell 171:456-469.e22.

Lefaki M, Papaevgeniou N, Chondrogianni N (2017) Redox regulation of proteasome function. Redox Biol 13:452-458.

Livak KJ, Schmittgen TD (2001) Analysis of relative gene expression data using real-time quantitative PCR and the $2-\Delta \Delta C T$ method. Methods 25:402-408.

Lorenzen I, Mullen L, Bekeschus S, Hanschmann EM (2017) Redox regulation of inflammatory processes is enzymatically controlled. Oxid Med Cell Longev 2017:8459402-8459423.

Martínez-Moreno A, Rodríguez-Durán LF, Escobar ML (2011) Late protein synthesis-dependent phases in CTA long-term memory: BDNF requirement. Front Behav Neurosci 5:61.

McGaugh JL (2000) Memory. A century of consolidation. Science 287:248-251. 
Naseri Kouzehgarani G, Bothwell MY, Gillette MU (2020) Circadian rhythm of redox state regulates membrane excitability in hippocampal CA1 neurons. Eur J Neurosci 51:34-46.

Olshina MA, Arkind G, Kumar Deshmukh F, Fainer I, Taranavsky M, Hayat D, Ben-Dor S, Ben-Nissan G, Sharon M (2020) Regulation of the 20S Proteasome by a novel family of inhibitory proteins. Antioxid Redox Signal 32:636-655.

Pelkey KA, Chittajallu R, Craig MT, Tricoire L, Wester JC, McBain CJ (2017) Hippocampal GABAergic inhibitory interneurons. Physiol Rev 97:1619-1747.

Rappaport AN, Jacob E, Sharma V, Inberg S, Elkobi A, OunallahSaad H, Pasmanik-Chor M, Edry E, Rosenblum K (2015) Expression of quinone reductase-2 in the cortex is a muscarinic acetylcholine receptor-dependent memory consolidation constraint. J Neurosci 35:15568-15581.

Reybier K, Perio P, Ferry G, Bouajila J, Delagrange P, Boutin JA, Nepveu $F$ (2011) Insights into the redox cycle of human quinone reductase 2. Free Radic Res 45:1184-1195.

Rosenblum K, Meiri N, Dudai Y (1993) Taste memory: the role of protein synthesis in gustatory cortex. Behav Neural Biol 59:49-56.

Rudy B, Fishell G, Lee S, Hjerling-Leffler J (2011) Three groups of interneurons account for nearly $100 \%$ of neocortical GABAergic neurons. Dev Neurobiol 71:45-61.

Santini E, Huynh TN, Klann E (2014) Mechanisms of translation control underlying long-lasting synaptic plasticity and the consolidation of long-term memory. Prog Mol Biol Transl Sci 122:131-167.

Sharma V, Sood R, Khlaifia A, Eslamizade MJ, Hung TY, Lou D, Asgarihafshejani A, Lalzar M, Kiniry SJ, Stokes MP, Cohen N, Nelson AJ, Abell K, Possemato AP, Gal-Ben-Ari S, Truong VT, Wang P, Yiannakas A, Saffarzadeh F, Cuello AC, et al. (2020) elF2 $\alpha$ controls memory consolidation via excitatory and somatostatin neurons. Nature 586:412-416.
Shrestha P, Ayata P, Herrero-Vidal P, Longo F, Gastone A, LeDoux JE, Heintz N, Klann E (2020) Cell-type-specific drug-inducible protein synthesis inhibition demonstrates that memory consolidation requires rapid neuronal translation. Nat Neurosci 23:281-292.

Sies $\mathrm{H}$ (2017) Hydrogen peroxide as a central redox signaling molecule in physiological oxidative stress: oxidative eustress. Redox Biol 11:613-619.

Sonavane M, Hayat F, Makarov M, Migaud ME, Gassman NR (2020) Dihydronicotinamide riboside promotes cell-specific cytotoxicity by tipping the balance between metabolic regulation and oxidative stress. PLoS One 15:e0242174.

Song C, Ehlers VL, Moyer JR (2015) Trace fear conditioning differentially modulates intrinsic excitability of medial prefrontal cortexbasolateral complex of amygdala projection neurons in infralimbic and prelimbic cortices. J Neurosci 35:13511-13524.

Squire LR, Genzel L, Wixted JT, Morris RG (2015a) Memory consolidation. Cold Spring Harb Perspect Biol 7:a021766.

Squire LR, Genzel L, Wixted JT, Morris RG (2015b) Memory consolidation. Cold Spring Harb Perspect Biol 7:a021766.

Tremblay R, Lee S, Rudy B (2016) GABAergic interneurons in the neocortex: from cellular properties to circuits. Neuron 91:260-292.

Urban-Ciecko J, Barth AL (2016) Somatostatin-expressing neurons in cortical networks. Nat Rev Neurosci 17:401-409.

Venniro M, Caprioli D, Zhang M, Whitaker LR, Zhang S, Warren BL, Cifani C, Marchant NJ, Yizhar O, Bossert JM, Chiamulera C, Morales M, Shaham Y (2017) The anterior insular cortex $\rightarrow$ central amygdala glutamatergic pathway is critical to relapse after contingency management. Neuron 96:414-427.e8.

Yiannakas A, Rosenblum K (2017) The insula and taste learning. Front Mol Neurosci 10:335. 